Article

\title{
Hydrotreatment Followed by Oxidative Desulfurization and Denitrogenation to Attain Low Sulphur and Nitrogen Bitumen Derived Gas Oils
}

\author{
Sandeep Badoga ${ }^{1}$, Prachee Misra ${ }^{1}$, Girish Kamath ${ }^{1}$, Ying Zheng ${ }^{2}$ and Ajay K. Dalai ${ }^{1, *}$ \\ 1 Catalysis and Chemical Reaction Engineering Laboratories, Department of Chemical Engineering, \\ University of Saskatchewan, Saskatoon, SK S7N 5A9, Canada; sab809@mail.usask.ca (S.B.); \\ prm173@mail.usask.ca (P.M.); gik089@mail.usask.ca (G.K.) \\ 2 School of Engineering, University of Edinburgh, Mayfield Road, Edinburgh EH9 3DW, UK; yzheng@unb.ca \\ * Correspondence: ajay.dalai@usask.ca
}

Received: 28 September 2018; Accepted: 3 December 2018; Published: 10 December 2018

check for updates

\begin{abstract}
To lower the sulphur content below $500 \mathrm{ppm}$ and to increase the quality of bitumen derived heavy oil, a combination of hydrotreating followed by oxidative desulfurization (ODS) and oxidative denitrogenation (ODN) is proposed in this work. NiMo $/ \gamma-\mathrm{Al}_{2} \mathrm{O}_{3}$ catalyst was synthesized and used to hydrotreat heavy gas oil (HGO) and light gas oil (LGO) at typical operating conditions of $370-390{ }^{\circ} \mathrm{C}, 9 \mathrm{MPa}, 1-1.5 \mathrm{~h}^{-1}$ space velocity and $600: 1 \mathrm{H}_{2}$ to oil ratio. $\gamma$-Alumina and alumina-titania supported Mo, P, Mn and W catalysts were synthesized and characterized using X-ray diffractions, $\mathrm{N}_{2}$ adsorption-desorption using Brunauer-Emmett-Teller (BET) method, X-ray photoelectron spectroscopy (XPS) and Fourier transform infrared spectroscopy (FT-IR). All catalysts were tested for the oxidation of sulphur and nitrogen aromatic compounds present in LGO and HGO using tert-butyl hydroperoxide (TBHP) as oxidant. The oxidized sulphur and nitrogen compounds were extracted using adsorption on activated carbon and liquid-liquid extraction using methanol. The determination of oxidation states of each metal using XPS confirmed the structure of metal oxides in the catalyst. Thus, the catalytic activity determined in terms of sulphur and nitrogen removal is related to their physico-chemical properties. In agreement with literature, a simplistic mechanism for the oxidative desulfurization is also presented. Mo was found to be more active in comparison to $\mathrm{W}$. Presence of Ti in the support has shown 8-12\% increase in ODS and ODN. The MnPMo/ $\gamma-\mathrm{Al}_{2} \mathrm{O}_{3}-\mathrm{TiO}_{2}$ catalyst showed the best activity for sulphur and nitrogen removal. The role of $\mathrm{Mn}$ and $\mathrm{P}$ as promoters to molybdenum was also discussed. Further three-stage ODS and ODN was performed to achieve less than 500 ppm in HGO and LGO. The combination of hydrotreatment, ODS and ODN has resulted in removal of $98.8 \mathrm{wt} . \%$ sulphur and $94.7 \mathrm{wt} . \%$ nitrogen from $\mathrm{HGO}$ and removal of $98.5 \mathrm{wt} . \%$ sulphur and $97.8 \mathrm{wt} . \%$ nitrogen from LGO.
\end{abstract}

Keywords: oxidative desulfurization; oxidative denitrogenation; hydrotreating; XPS; activated carbon; tert-butyl hydroperoxide

\section{Introduction}

Worldwide increase in industrialization has led to an increase in consumption of petroleum oil and coal [1]. It has raised serious environmental concerns due to the rise in sulphur oxide (SOx) levels in air. Therefore, environmental protection agencies (EPA) such as US EPA limits the sulphur levels to $15 \mathrm{ppm}$ in diesel fuel, which is expected to be further lowered to $10 \mathrm{ppm}$. On the other hand, the gas oil extracted from unconventional sources such as, oil sands and shale oil contain high amount of sulphur and nitrogen impurities. For instance the oil sands bitumen derived heavy gas oil (HGO) 
contains $\sim 40,000$ ppm sulphur and $\sim 4000$ ppm nitrogen [2]. The bitumen derived gas oils (HGO, light gas oil (LGO) and naphtha) are upgraded onsite via hydrotreating to lower the sulphur and nitrogen content before sending them to further processing in existing refineries. Hydrotreating is a catalytic process operating in the presence of hydrogen at high pressure (8-12 $\mathrm{MPa}$ ) and temperatures $\left(350-400{ }^{\circ} \mathrm{C}\right)$ to remove sulphur and nitrogen via processes known as hydrodesulfurization (HDS) and hydrodenitrogenation (HDN), respectively. Typically, for HGO the hydrotreating can lower the sulphur and nitrogen content to $\sim 2200 \mathrm{ppm}$ and $1700 \mathrm{ppm}$, respectively. To further lower the sulphur content from $\sim 2200 \mathrm{ppm}$ during upgrading requires severe hydrotreating operating conditions such as higher pressures, temperatures and hydrogen flowrates to remove sulphur from refractory molecules such as alkyl substituted dibenzothiophenes (DBT). Increasing the temperature leads to cracking of oil and higher pressures lead to an increase in saturation of aromatics and higher hydrogen consumption, thus degrading the oil quality, in addition to decline in catalyst lifespan. Moreover, huge capital investment is required for high-pressure processes.

The alternative processes such as adsorption and oxidative desulfurization and denitrogenation has been of interest to achieve ultra-low sulphur level in oil because of very mild operating conditions and no usage of hydrogen. Various adsorbents including activated carbon, ionic resins, metal organic frameworks, metal oxides and zeolites have been used to adsorb sulphur containing compounds from diesel oil [3-10]. Ganiyu et al. [6] utilized activated carbon doped with $1.0 \mathrm{wt}$ \% boron to selectively adsorb 4,6-DMDBT from model fuel. Srivastav and Srivastava [7] carried out the adsorption of DBT dissolved in hexanes on commercial grade activated alumina and Li et al. [4] presented a study on the challenges associated with removal of aromatic sulphur compounds using metal-organic frameworks. McKinley and Angelici [9] used silver salts on SBA-15 for adsorptive removal of DBT from simulated hydrotreated petroleum feedstocks. They were able to lower the sulphur level from $411 \mathrm{ppm}$ to $8 \mathrm{ppm}$.

Oxidative desulfurization (ODS) is one of the alternate routes for deep desulfurization. In ODS process (as shown in Figure 1), the sulphur present in compounds such as DBT is first oxidized to sulfoxides or sulfones in the presence of oxidizing agents such as hydrogen peroxide, organic peroxides, nitrogen oxide or air and catalysed by organic acids, heteropolyic acids or solid catalysts. The oxidation of sulphur leads to increase in polarity of sulphur containing compounds. Therefore, the sulfoxides and sulfones were easily extracted from the oil by using polar solvents or adsorbents, thus achieving deep desulfurization. Most commonly tested solvents include dimethylsulfoxide (DMSO), dimethylformamide (DMF), acetonitrile, methanol and acetone [11,12]. There are several well-known disadvantages with solvent exactions such as toxicity, reusability, disposal, explosiveness and cost. Therefore, selection of solvent is a challenge. DMSO poses challenges during recovery due to similar boiling point, whereas acetonitrile is highly polar and extracts lots of aromatics [11]. Methanol is a good solvent for extracting sulfones however, it has similar density as diesel and thus separation is difficult. The ease of oxidation of various sulphur containing compounds depends on the electron densities on the sulphur atom. Sulphur with higher electron densities are easier to oxidize, hence, follows the order 4,6-DMDBT $>$ DBT $>$ BT $>$ Thiophene [13]. Bunthid et al. [14] have utilized formic acid and $\mathrm{H}_{2} \mathrm{O}_{2}$ as oxidizing agent to oxidize DBT. The corresponding sulfone from the solution was then extracted by adsorption on pyrolysis char. The small amount of water remaining was extracted by drying over anhydrous sodium sulphate. They reported $72 \%$ sulphur removal. In another study, Ahmad et al. [15], used acetic acid as a catalyst for sulphur oxidation with $\mathrm{H}_{2} \mathrm{O}_{2}$. They used Fuller's earth for the adsorption of sulfones and achieved $50 \%$ sulphur removal. 


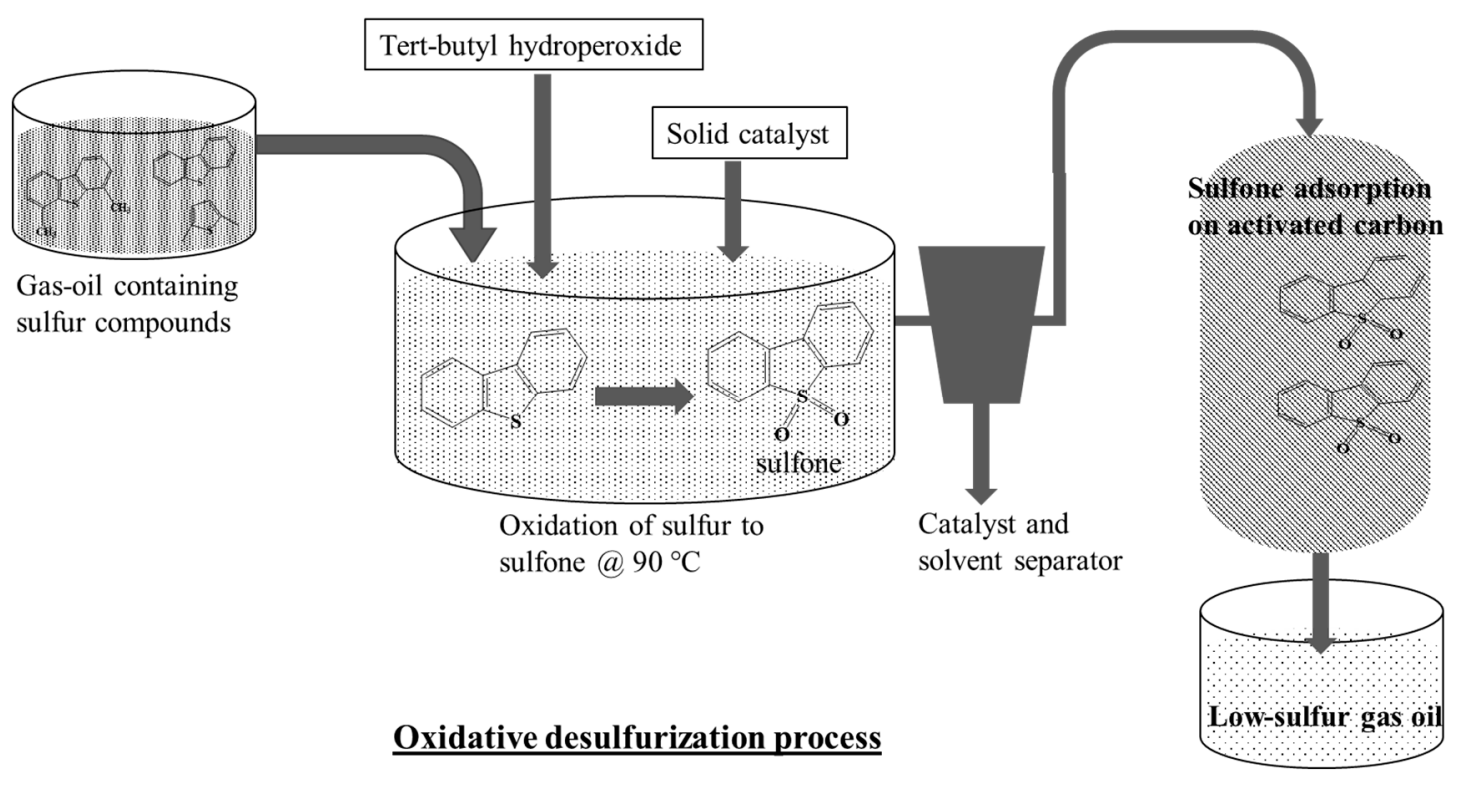

Figure 1. Schematic for Oxidative desulfurization process.

Palaic et al. [16] studied the oxidative desulfurization of diesel fuels for the removal of refractory sulphur compounds which are difficult to remove during conventional hydrotreating. They utilized hydrogen peroxide as oxidant and acetic acid as catalyst and performed reactions in a batch reactor. The effects of process conditions of ultrasound-assisted ODS with $N, N$ dimethylformamide and methanol as extraction solvents were also reported. They successfully removed $98 \%$ sulphur from 4000 ppm DBT spiked diesel fuel. The usage of acid catalyst such as acetic acid or formic acid for oxidation of sulphur compounds requires recovery of these organic acids after treatment. It requires additional set up for recovery of such corrosive and toxic organic acids. Therefore, in view of this, solid catalysts were utilized. Fattahi et al. [17] synthesized $\mathrm{CoMo} / \gamma-\mathrm{Al}_{2} \mathrm{O}_{3}$ catalyst with different $\mathrm{Co} /$ Mo ratio and utilized it for the oxidative desulfurization of DBT and benzothiophene (BT) using $\mathrm{H}_{2} \mathrm{O}_{2}$ as oxidizing agent. They reported $90 \%$ removal of DBT and $30 \%$ removal of BT. Chica et al. [18] studied the effect of catalyst on ODS in a continuous fixed bed reactor for model feed containing different types of sulphur compounds including thiophenes and alkyl substituted DBTs. Tert-butyl hydroperoxide was utilized as oxidizing agent. They reported that $\mathrm{MoOx} / \mathrm{Al}_{2} \mathrm{O}_{3}$ was very active but had faster deactivation rate. However, the Ti-MCM-41 was stable and active for longer time. Gatan et al. [19] from UOP also proposed the oxidation with organic perpoxide in the presence of heterogeneous catalyst followed by separation via adsorption and/or extraction. They proposed ODS as complementary to hydrodesulfurization for the removal of refractory sulphur compounds to attain ultra-low sulphur diesel. Leng et al. [20] synthesized titanium doped hierarchical mordenite to catalyse ODS of DBT in octane. They used acetonitrile for the extraction of sulfones and were successful in lowering the sulphur content from $1000 \mathrm{ppm}$ to $14 \mathrm{ppm}$. Lorencon et al. [21] utilized titanate nanotubes and $\mathrm{H}_{2} \mathrm{O}_{2}$ for the oxidation of DBT in model feed (500 ppm sulphur) and evidenced $\sim 98 \%$ sulphur removal. Tian et al. [22] performed ODS using $\mathrm{H}_{2} \mathrm{O}_{2}$ and phosphomolybic acid supported on silica for the removal of DBT and BT from model oil ( 400 ppm sulphur) and were successful in removing 95\% sulphur. García-Gutiérrez et al. [23] utilized heterogeneous tungsten catalyst for oxidation of sulphur compounds in diesel ( $\sim 320$ ppm sulphur) using $\mathrm{H}_{2} \mathrm{O}_{2}$ as oxidizing agent and achieved $\sim 70 \%$ removal. Therefore, it has been seen that various catalyst systems have been tested for the oxidation of sulphur present in model and simulated diesel fuels. Moreover, the extraction of sulfones and sulfoxides from oil was carried out using both solvent extraction and adsorption.

The oxidation using peroxide in the presence of catalyst is not only selective to oxidize sulphur in heterocyclic aromatic compounds such as DBTs and alkyl substitute DMDBTs but it also oxidizes nitrogen containing aromatic compounds present in real feed. The oxidation of nitrogen containing 
aromatic compounds such as quinoline, indole and carbazole is a complex reaction. According to the literature [24-26], it was found that the peroxide group oxidizes that carbon in aromatic ring, which is having least electron density to form -oxy or -oxyl compounds. Further oxidation leads to ring opening and formation of various oxygenated products of ketone and carboxylic acid category. A study by Ogunlaja et al. [25] also reported the oxidation of nitrogen in quinoline to form of quinoline $\mathrm{N}$-oxide. The oxidation follows the order indole $>$ quinoline $>$ acridine $>$ carbazole. However, the oxidation of nitrogen compounds increases their polarity, which makes it easy to remove organonitrogen compounds from oil by adsorption or extraction, thus resulting in oxidative denitrogenation (ODN). The removal of nitrogen prevents the downstream catalysts from poisoning and hence ODN increases the quality of the treated HGO and LGO.

Therefore, to keep bitumen-based fuels competitive in the current market, the production of low sulphur and low nitrogen HGO and LGO is required, which still remains a challenge to industry. Thus, the potential of ODS and ODN to further lower the sulphur and nitrogen level in hydrotreated LGO and $\mathrm{HGO}$ using heterogeneous catalyst needs to be explored. In this work, $\mathrm{NiMo} / \gamma-\mathrm{Al}_{2} \mathrm{O}_{3}$ catalyst was synthesized and utilized to hydrotreat the HGO and LGO at typical industrial conditions of $370-390{ }^{\circ} \mathrm{C}$, $9 \mathrm{MPa}, 1-1.5 \mathrm{~h}^{-1}$ LHSV and 1:600 oil to $\mathrm{H}_{2}$ ratio, in fixed bed flow reactor, to generate hydrotreated gas oil for ODS and ODN process. Further, alumina and alumina-titania supported Mo, W, Mn and P catalysts were synthesized and tested for the oxidation of sulphur and nitrogen compounds present in real gas oil using tert-butylhydroperoxide (TBHP) as oxidizing agent. The extraction of oxidized sulphur and nitrogen compounds was carried out by adsorption on activated carbon and compared with liquid extraction using methanol. This study on integration of conventional hydrotreating technology with ODS and ODN for upgrading bitumen derived gas oil has resulted in lowering the sulphur levels to less than 500 ppm in both HGO and LGO, which can be further lowered down in existing refineries to meet the EPA regulations for diesel fuel. Additionally, the nitrogen levels for HGO were brought down to $200 \mathrm{ppm}$, which enhances the quality of crude oil and eliminates the nitrogen removal process prior to refining of treated HGO. The catalysts were thoroughly characterized using BET, XRD, FTIR and XPS and their physico-chemical properties were related to their catalytic activities.

\section{Results and Discussion}

\subsection{Material Characterization}

\subsection{1. $\mathrm{N}_{2}$ Adsorption-Desorption Analysis}

The textural properties of all the materials synthesized in this work were determined using $\mathrm{N}_{2}$ adsorption-desorption analysis. Table 1 shows the surface area, pore volume and pore diameter of each material. The surface area of $\gamma-\mathrm{Al}_{2} \mathrm{O}_{3}$ decreased from $330 \mathrm{~m}^{2} / \mathrm{g}$ to $300 \mathrm{~m}^{2} / \mathrm{g}$ and pore volume decreased from $0.90 \mathrm{~cm}^{3} / \mathrm{g}$ to $0.75 \mathrm{~cm}^{3} / \mathrm{g}$ on addition of $\mathrm{TiO}_{2}$. However, the pore structure stayed intact, as evidenced from the pore size distribution and adsorption-desorption profiles (figure not shown). The $\gamma-\mathrm{Al}_{2} \mathrm{O}_{3}$ and $\gamma-\mathrm{Al}_{2} \mathrm{O}_{3}-\mathrm{TiO}_{2}$ exhibited the type IV isotherm with $\mathrm{H} 1$ type hysteresis loop confirming the mesoporous structure (Figure 2). On addition of $\mathrm{Mo}, \mathrm{W}, \mathrm{P}$ and $\mathrm{Mn}$ on $\gamma-\mathrm{Al}_{2} \mathrm{O}_{3}-\mathrm{TiO}_{2}$, the resulting materials maintained the type IV isotherm. The decline in pore volume, surface area and pore diameter in catalysts $\mathrm{Mo} / \gamma-\mathrm{Al}_{2} \mathrm{O}_{3}, \mathrm{~W} / \gamma-\mathrm{Al}_{2} \mathrm{O}_{3}, \mathrm{Mo} / \gamma-\mathrm{Al}_{2} \mathrm{O}_{3}-\mathrm{TiO}_{2}, \mathrm{~W} / \gamma-\mathrm{Al}_{2} \mathrm{O}_{3}-\mathrm{TiO}_{2}, \mathrm{PMo} / \gamma-\mathrm{Al}_{2} \mathrm{O}_{3}-\mathrm{TiO}_{2}$ and $\mathrm{MnPMo} / \gamma-\mathrm{Al}_{2} \mathrm{O}_{3}-\mathrm{TiO}_{2}$ is proportional to the amounts of metals (Mo, W, $\mathrm{P}, \mathrm{Mn}$ ) loaded on alumina and alumina-titania supports. 
Table 1. Textural properties of the catalysts used for oxidative desulfurization and denitrogenation. (error $\pm 3.0 \%$ ).

\begin{tabular}{cccc}
\hline Catalyst & Surface Area $\left(\mathbf{m}^{2} / \mathbf{g}\right)$ & Pore Volume $(\mathbf{c c} / \mathbf{g})$ & Pore Diameter $(\mathbf{n m})$ \\
\hline$\gamma-\mathrm{Al}_{2} \mathrm{O}_{3}$ & 330 & 0.90 & 7.6 \\
$\gamma-\mathrm{Al}_{2} \mathrm{O}_{3}-\mathrm{TiO}_{2}$ & 300 & 0.75 & 7.1 \\
$\mathrm{Mo} / \gamma-\mathrm{Al}_{2} \mathrm{O}_{3}$ & 242 & 0.60 & 7.2 \\
$\mathrm{Mo} / \gamma-\mathrm{Al}_{2} \mathrm{O}_{3}-\mathrm{TiO}_{2}$ & 210 & 0.50 & 7.0 \\
$\mathrm{~W} / \gamma-\mathrm{Al}_{2} \mathrm{O}_{3}$ & 240 & 0.62 & 7.3 \\
$\mathrm{~W} / \gamma-\mathrm{Al}_{2} \mathrm{O}_{3}-\mathrm{TiO}_{2}$ & 208 & 0.49 & 7.0 \\
$\mathrm{PMo} / \gamma-\mathrm{Al}_{2} \mathrm{O}_{3}-\mathrm{TiO}_{2}$ & 181 & 0.46 & 6.9 \\
$\mathrm{MnPMo} / \gamma-\mathrm{Al}_{2} \mathrm{O}_{3}-\mathrm{TiO}_{2}$ & 165 & 0.43 & 6.9 \\
\hline
\end{tabular}

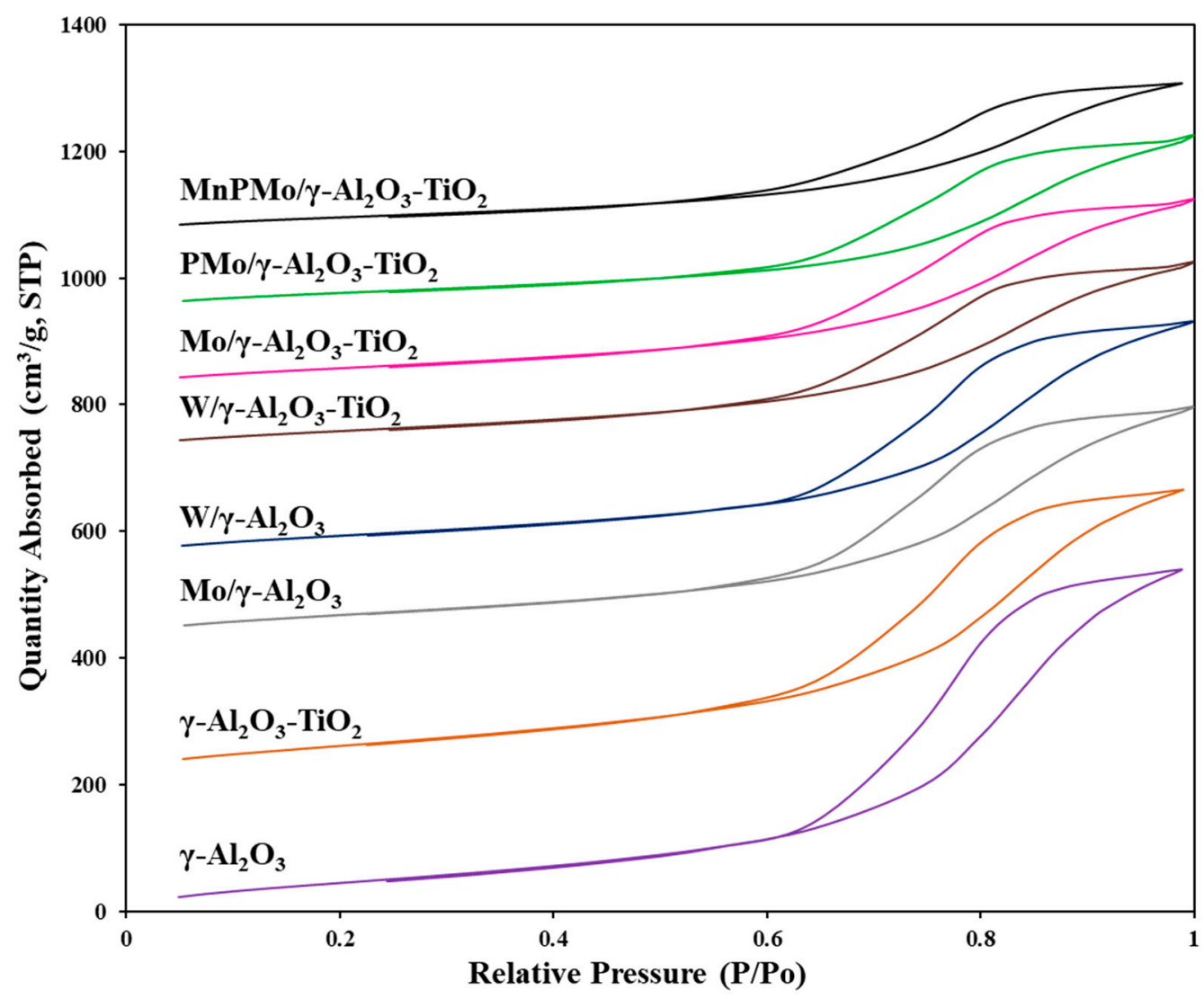

Figure 2. $\mathrm{N}_{2}$ adsorption-desorption isotherms for all materials.

\subsubsection{X-ray Diffraction Analysis}

The X-ray diffraction analysis was performed to determine the presence of various crystalline phase of metals doped on the $\gamma-\mathrm{Al}_{2} \mathrm{O}_{3}$ and $\gamma-\mathrm{Al}_{2} \mathrm{O}_{3}-\mathrm{TiO}_{2}$ support materials. The XRD profile for each catalyst is shown in Figure 3. The peaks at $2 \theta=37.0^{\circ}, 46.0^{\circ}$ and $66.7^{\circ}$ in the XRD profile for $\gamma-\mathrm{Al}_{2} \mathrm{O}_{3}$ corresponds to the planes of cubic $\mathrm{Al}_{2} \mathrm{O}_{3}$ [27]. The additional peaks at $2 \theta=25.5,37.9$, 48.0, 54.0, 55.0 and 62.8 degrees in XRD profile for $\gamma-\mathrm{Al}_{2} \mathrm{O}_{3}-\mathrm{TiO}_{2}$ material is due to the presence of $\mathrm{TiO}_{2}$ in anatase phase, which is the active phase of titania for the reaction [28]. The addition of $\mathrm{W}$ on alumina and alumina-titania, does not show any additional peak in XRD profile of $\mathrm{W} / \gamma-\mathrm{Al}_{2} \mathrm{O}_{3}$ and $\mathrm{W} / \gamma-\mathrm{Al}_{2} \mathrm{O}_{3}-\mathrm{TiO}_{2}$ indicating the fine dispersion of tungsten oxide. However, the materials $\mathrm{Mo} / \gamma-\mathrm{Al}_{2} \mathrm{O}_{3}$ and $\mathrm{Mo} / \gamma-\mathrm{Al}_{2} \mathrm{O}_{3}-\mathrm{TiO}_{2}$ showed small peaks at $2 \theta=23.3^{\circ}$ and $27.2^{\circ}$ corresponding to the presence of $\mathrm{MoO}_{3}$. There was no change observed in the crystal orientation on addition of phosphorous. The XRD profile for $\mathrm{MnPMo} / \gamma-\mathrm{Al}_{2} \mathrm{O}_{3}-\mathrm{TiO}_{2}$ further showed new peaks at $2 \theta=25.9^{\circ}$,

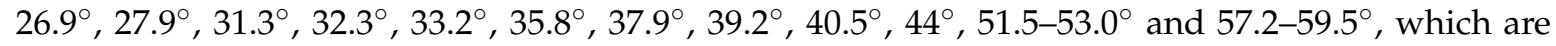


related to the presence of $\alpha-\mathrm{MnMoO}_{4}$ [29]. The intense peak at $2 \theta=25.9^{\circ}$ may correspond to the 220 plane of $\mathrm{MnMoO}_{4}$. These reflections are in accordance with JCPDS Card No: 01-72-0285 as reported by Veerasubramani et al. [30]. Additionally, the peaks at $2 \theta=21.0^{\circ}, 26.9^{\circ}, 27.9^{\circ}, 32.3^{\circ}, 33.2^{\circ}$, $40.5^{\circ}, 44^{\circ}, 51.5-53.0^{\circ}$ and $57.2-59.5^{\circ}$ can also be attributed to the presence of $\mathrm{Mo}_{4} \mathrm{O}_{11}$ as described by Yang et al. [29]. Therefore, further details on the peak elucidation can be obtained from XPS analysis.

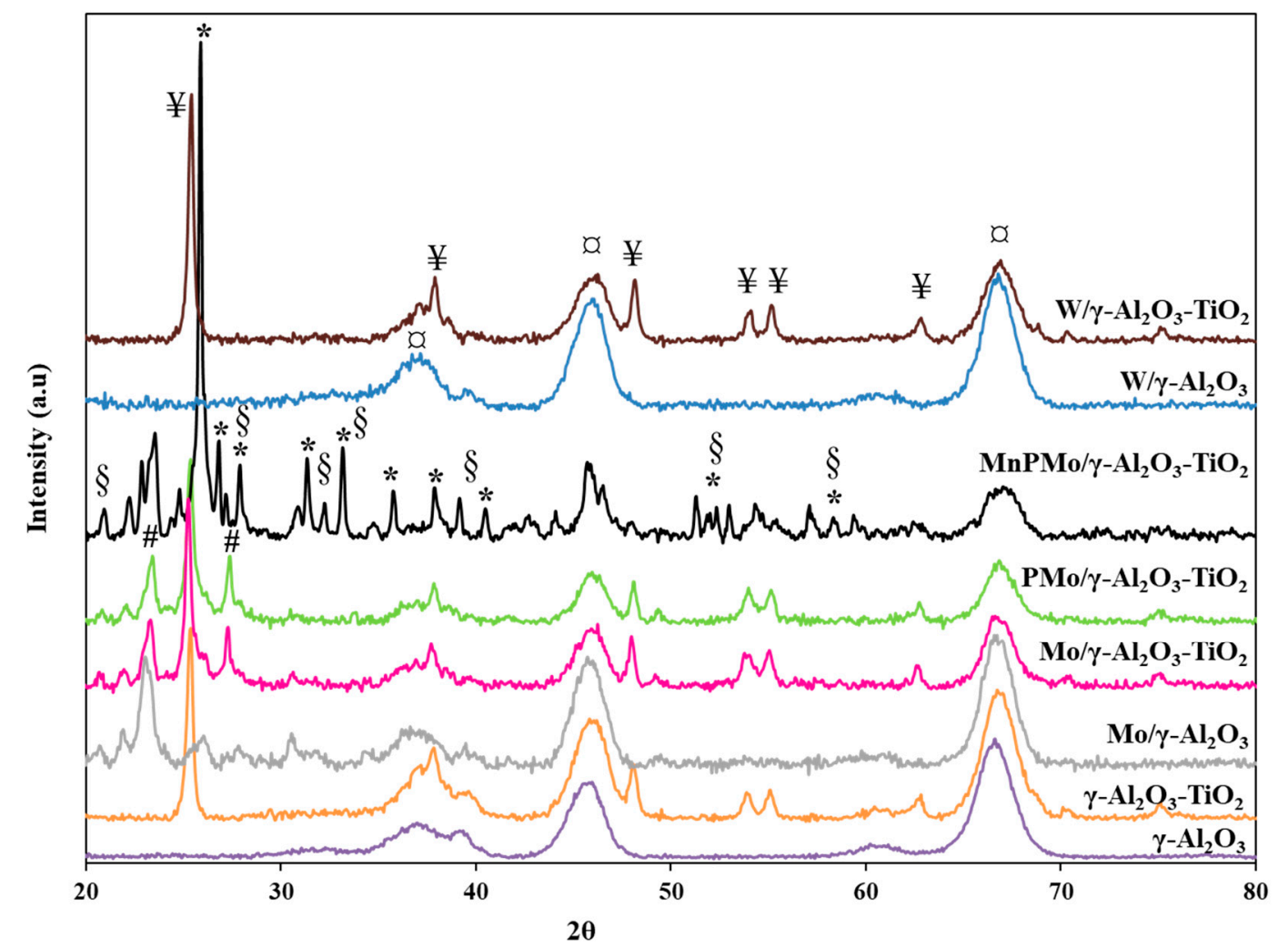

Figure 3. X-ray diffractograms of all catalysts. ( $\S-\mathrm{Mo}_{4} \mathrm{O}_{11}, ¥-\mathrm{TiO}_{2}$ (anatase phase), - - planes of $\gamma-\mathrm{Al}_{2} \mathrm{O}_{3}$, \#- $\mathrm{MoO}_{3}$ ).

\subsubsection{Fourier Transformed Infrared Spectroscopy}

The FT-IR spectroscopy was performed to determine the presence of various vibrational bands corresponding to the functional groups and active metals. The FT-IR spectra for all the materials in this study are shown in Figure 4. The band in the range of $400-700 \mathrm{~cm}^{-1}$ with few spikes at $600-700 \mathrm{~cm}^{-1}$ in the spectra for $\gamma-\mathrm{Al}_{2} \mathrm{O}_{3}$ is due to the stretching of $\mathrm{Al}-\mathrm{O}$ bonds in octahedral alumina. The band between 750-950 $\mathrm{cm}^{-1}$ represents the vibration of Al-O bond in tetrahedrally coordinated $\mathrm{Al}$ [31]. This type of broad band from $400-950 \mathrm{~cm}^{-1}$ with no sharp peaks is a typical for poorly ordered material such as $\gamma-\mathrm{Al}_{2} \mathrm{O}_{3}$. The IR bands corresponding to the vibration of Ti-O bonds appearing at $400-760 \mathrm{~cm}^{-1}$ are superimposed with Al-O vibrations and were not distinguished [32]. The IR active bonds corresponding to molybdenum and tungsten were not clearly identified in Mo and $\mathrm{W}$ supported $\gamma-\mathrm{Al}_{2} \mathrm{O}_{3}$ and $\gamma-\mathrm{Al}_{2} \mathrm{O}_{3}-\mathrm{TiO}_{2}$ materials, as the broad peak of $400-700 \mathrm{~cm}^{-1}$ masks most of the peaks. The broad band at $1050-1250 \mathrm{~cm}^{-1}$ in IR spectra of $\mathrm{PMo} / \gamma-\mathrm{Al}_{2} \mathrm{O}_{3}-\mathrm{TiO}_{2}$ can be assigned to the superimposition of the bands corresponding symmetrical vibrations of $\mathrm{PO}_{4}$ and asymmetrical stretching of P-O-P [33,34]. The catalyst $\mathrm{MnPMo} / \gamma-\mathrm{Al}_{2} \mathrm{O}_{3}-\mathrm{TiO}_{2}$ showed additional IR bands at $719 \mathrm{~cm}^{-1}, 725 \mathrm{~cm}^{-1}, 796 \mathrm{~cm}^{-1}, 865 \mathrm{~cm}^{-1}$ and $910-970 \mathrm{~cm}^{-1}$, which are the characteristic peaks for tetrahedrally coordinated $\mathrm{Mo}$ in $\alpha-\mathrm{MnMoO}_{4}[35,36]$. The presence of $\alpha-\mathrm{MnMoO} 4$ was also detected in XRD analysis (Section 2.1.2) of the $\mathrm{MnPMo} / \gamma-\mathrm{Al}_{2} \mathrm{O}_{3}-\mathrm{TiO}_{2}$ catalyst. Additionally, the peaks at $865 \mathrm{~cm}^{-1}$ and $910 \mathrm{~cm}^{-1}$ could also be assigned to the molybdenum present in $\mathrm{Mo}_{4} \mathrm{O}_{11}$ species [37]. 


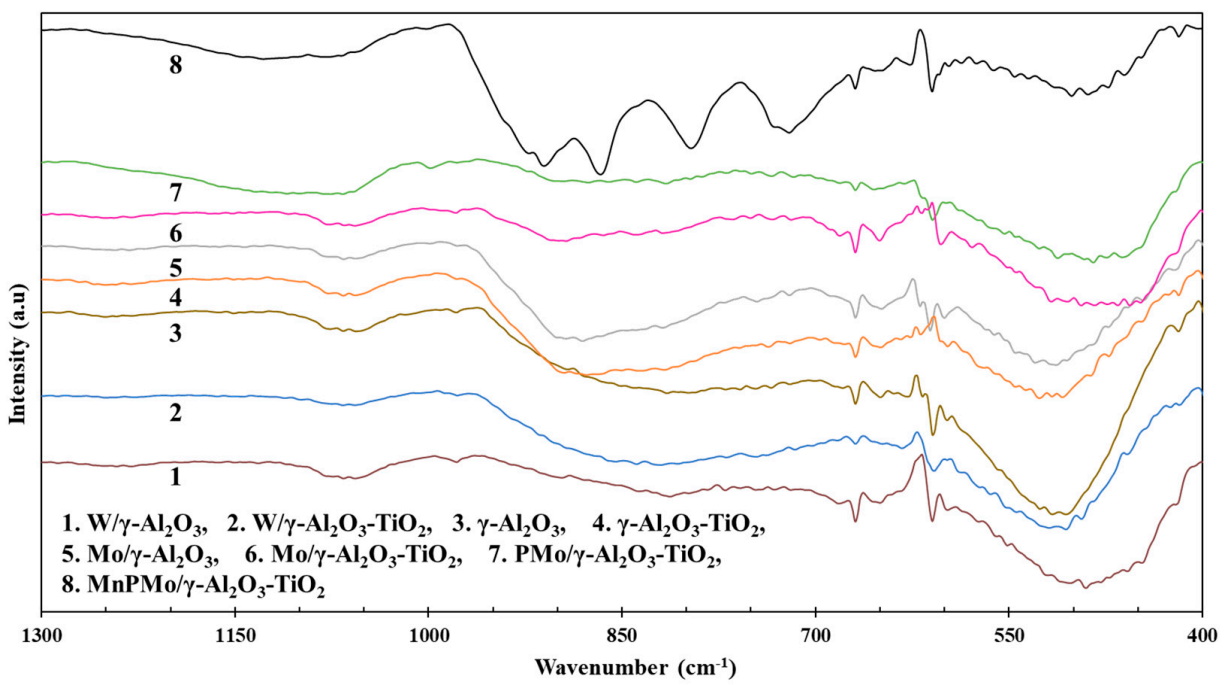

Figure 4. Fourier transform-infrared (FT-IR) spectra of supported catalysts.

\subsubsection{X-ray Photoelectron Spectroscopy}

The X-ray photoelectron spectroscopy (XPS) was employed to determine the oxidation state of $\mathrm{Mo}$ and $\mathrm{Mn}$ in $\mathrm{TiO}_{2}-\mathrm{Al}_{2} \mathrm{O}_{3}$ supported catalysts. Both $\mathrm{Mo}$ and $\mathrm{Mn}$ tend to form various oxides with different oxidation states. The XPS spectra for Mn 2p and 3s region are shown in Figure 5. The Mn 2p spectrum (Figure $5 \mathrm{~b}$ ) shows the spin-orbit doublet at $641.6 \mathrm{eV}$ and $652.9 \mathrm{eV}$ representing $2 \mathrm{p} 3 / 2$ and $2 \mathrm{p} 1 / 2$ electronic states $(\Delta \mathrm{E}$ of $11.3 \mathrm{eV})$. The $\mathrm{Mn} 2 \mathrm{p}$ spectrum also shows a satellite feature at $645-648 \mathrm{eV}$, which is a characteristic of $\mathrm{Mn}^{2+}[38,39]$. The shake-up satellite feature appears when the $\mathrm{x}$-ray ejected core electron excites a valance electron to a higher energy level, thus, reducing the energy of core electron leading to appearance of satellite at few $\mathrm{eV}$ lower than the core level binding energy. Therefore, the Mn 2p XPS spectra indicates the presence of +2 oxidation state of manganese. To further confirm the oxidation state of manganese in catalyst $\mathrm{Mn} / \mathrm{P} / \mathrm{Mo} / \mathrm{Al}-\mathrm{Ti}$, the Mn 3s XPS spectra was analysed. The $\Delta \mathrm{E}$ between the spilt $3 \mathrm{~s}$ peaks indicates the oxidation state. The splitting of $3 \mathrm{~s}$ peak is due to the interaction of $3 \mathrm{~s}$ core hole (after photoemission) and $3 \mathrm{~d}$ valance electrons. The energy difference between the parallel and antiparallel spin configuration of both $3 \mathrm{~s}$ and $3 \mathrm{~d}$ determines the split. Thus, the $\Delta \mathrm{E}$ for $3 \mathrm{~s}$ splitting in +2 oxidation sate of manganese is expected to be highest due to $3 \mathrm{~d} 5 \mathrm{high}$ spin configuration [40]. The reported difference in binding energy ( $\triangle \mathrm{E})$ for $\mathrm{Mn}^{2+}, \mathrm{Mn}^{3+}$ and $\mathrm{Mn}^{4+}$ is $\sim 6.0 \mathrm{eV}, 5.3 \mathrm{eV}$ and $4.7 \mathrm{eV}$, respectively [41]. The $\mathrm{Mn} 3 \mathrm{~s} \mathrm{XPS}$ spectra for catalyst $\mathrm{MnPMo} / \gamma-\mathrm{Al}_{2} \mathrm{O}_{3}-\mathrm{TiO}_{2}$ shows peak split $\Delta \mathrm{E}$ of $6.0 \mathrm{eV}$ confirming the +2 oxidation state of manganese. This concludes that manganese is present in the form of and $\mathrm{MnMoO} 4$ as shown by XRD analysis.
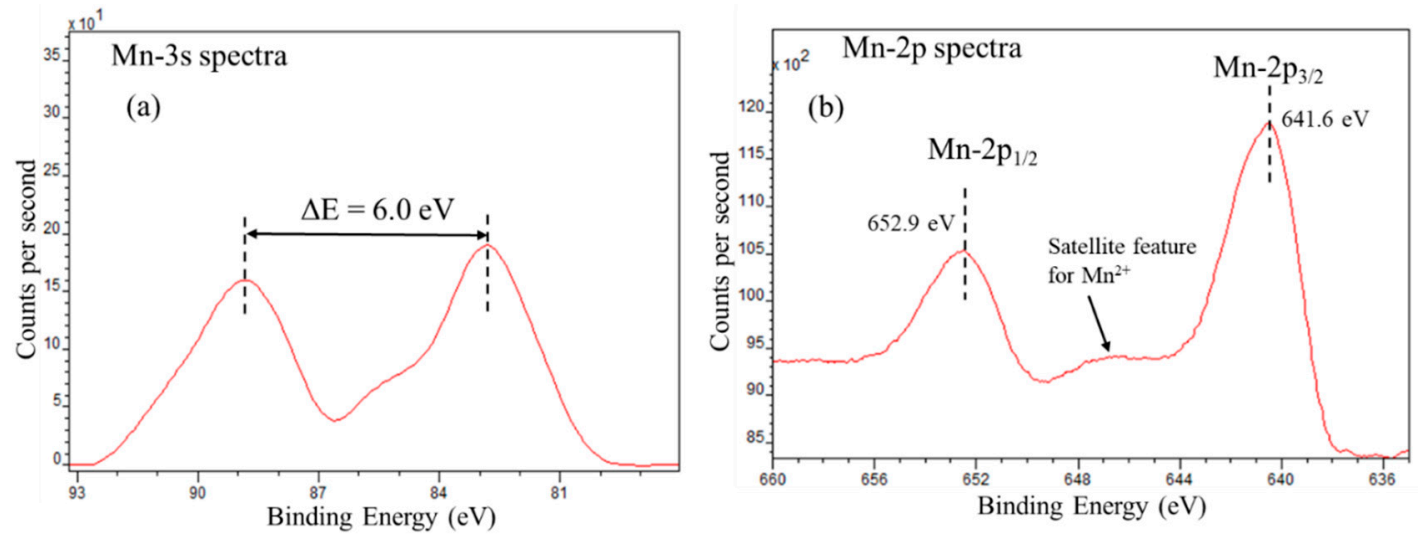

Figure 5. X-ray photoelectron (XPS) spectra for manganese in $\mathrm{MnPMo} / \mathrm{TiO}_{2}-\mathrm{Al}_{2} \mathrm{O}_{3}$ catalyst, (a) $\mathrm{Mn}-3 \mathrm{~s}$ spectra and (b) Mn-2p spectra. 
The Mo 3d XPS spectra for materials $\mathrm{Mo} / \gamma-\mathrm{Al}_{2} \mathrm{O}_{3}-\mathrm{TiO}_{2}, \mathrm{PMo} / \gamma-\mathrm{Al}_{2} \mathrm{O}_{3}-\mathrm{TiO}_{2}$ and $\mathrm{MnPMo} / \gamma-\mathrm{Al}_{2} \mathrm{O}_{3}-\mathrm{TiO}_{2}$ is shown is Figure 6. The Mo $3 \mathrm{~d}$ region shows well separated spin-orbit component $3 \mathrm{~d} 5 / 2$ and $3 \mathrm{~d} 3 / 2$ with $\Delta \mathrm{E} \approx 3.2 \mathrm{eV}$ [38]. The binding energy of $3 \mathrm{~d} 5 / 2$ peak indicates the oxidation state of molybdenum. For $+4,+5$ and +6 oxidation states of molybdenum, the $3 \mathrm{~d} 5 / 2$ peak appears at binding energy $\sim 229.7 \mathrm{eV}, 231.5 \mathrm{eV}$ and $232.5 \mathrm{eV}$, respectively [42-44]. The peak fitting was performed using the CasaXPS Demo version and results are shown in Figure 6. The area under $3 \mathrm{~d} 3 / 2$ peak is kept constant to two-third of the $3 \mathrm{~d} 5 / 2$ peak area. The $\Delta \mathrm{E}$ was kept constant at $3.2 \mathrm{eV}$. It can be seen from Figure 6 a that $86 \%$ molybdenum in catalyst $\mathrm{Mo} / \gamma-\mathrm{Al}_{2} \mathrm{O}_{3}-\mathrm{TiO}_{2}$ is in +6 oxidation state indicating the presence of $\mathrm{MoO}_{3}$. On addition of phosphorus to this catalyst the increase in octahedral molybdenum was observed as shown in Mo 3d XPS in Figure 6b. It could be due the stronger interaction of phosphorus with surface hydroxyl groups present on the support material as explained in our previous work [45]. The review of influence of phosphorous on alumina supported hydrotreating catalyst by Iwamoto and Grimblot [46] also explained the formation of $\mathrm{AlPO}_{4}$ on the surface of alumina using surface hydroxyl groups. Thus, the interaction of phosphorus with support reduces the number of surface hydroxyl group for molybdenum to anchor and thus decreases the metal support interactions, resulting in formation of octahedral molybdenum.
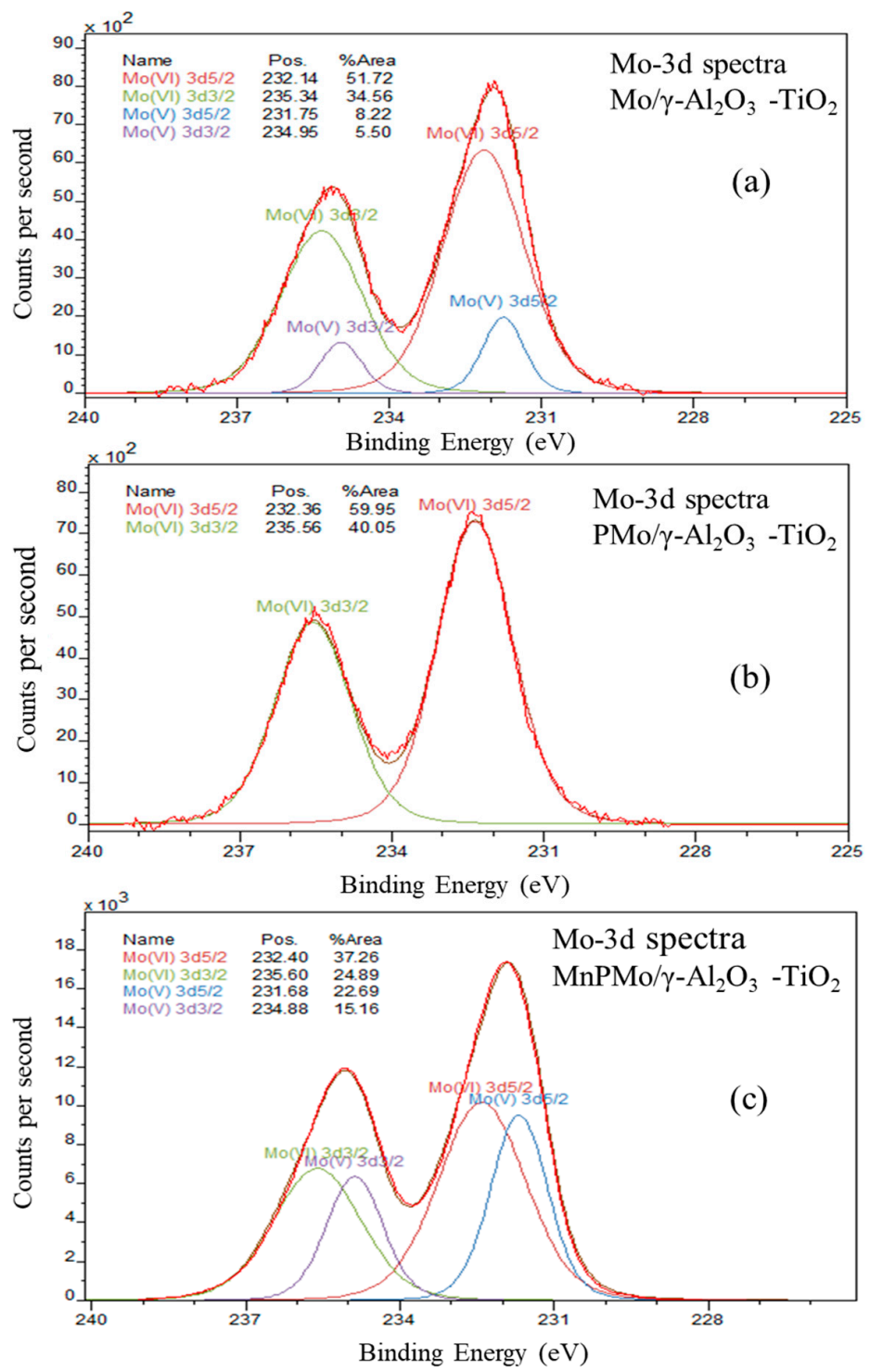

Figure 6. Mo $3 \mathrm{~d}$ XPS spectra for (a) $\mathrm{Mo} / \gamma-\mathrm{Al}_{2} \mathrm{O}_{3}-\mathrm{TiO}_{2}$, (b) $\mathrm{PMo} / \gamma-\mathrm{Al}_{2} \mathrm{O}_{3}-\mathrm{TiO}_{2}$ and (c) $\mathrm{MnPMo} / \gamma-\mathrm{Al}_{2} \mathrm{O}_{3}-\mathrm{TiO}_{2}$. 
The addition of manganese to the $\mathrm{PMo} / \gamma-\mathrm{Al}_{2} \mathrm{O}_{3}-\mathrm{TiO}_{2}$ catalyst has significantly altered the oxidation state of the molybdenum as seen from the Mo $3 \mathrm{~d}$ XPS of $\mathrm{MnPMo} / \gamma-\mathrm{Al}_{2} \mathrm{O}_{3}-\mathrm{TiO}_{2}$ (Figure 6c). Around $62 \%$ of the molybdenum is in +6 oxidation state and balance $(\sim 38 \%)$ is in +5 oxidation state. This indicates the presence of $\mathrm{Mo}_{4} \mathrm{O}_{11}$, which has a ratio of $1: 1$ for $\mathrm{Mo}^{+6}$ and $\mathrm{Mo}^{+5}$ and $\mathrm{MnMoO}_{4}$ which contains polymolybdate $(\mathrm{MoO} 4)^{-2}$ with +6 oxidation state for Mo [47]. This confirms the finding of $\mathrm{Mo}_{4} \mathrm{O}_{11}$ and $\mathrm{MnMoO}_{4}$ in $\mathrm{MnPMo} / \gamma-\mathrm{Al}_{2} \mathrm{O}_{3}-\mathrm{TiO}_{2}$ catalyst and supports the XRD conclusions.

The XPS analysis for determining the oxidation state of tungsten in $\mathrm{W} / \gamma-\mathrm{Al}_{2} \mathrm{O}_{3}$ and $\mathrm{W} / \gamma-\mathrm{Al}_{2} \mathrm{O}_{3}$ $-\mathrm{TiO}_{2}$ was also performed. The $4 \mathrm{f} \mathrm{W} \mathrm{XPS} \mathrm{spectra} \mathrm{(figure} \mathrm{not} \mathrm{shown)} \mathrm{shows} \mathrm{a} 4 \mathrm{f}_{7 / 2}$ and $4 \mathrm{f}_{5 / 2}$ doublet with $4 \mathrm{f} 7 / 2$ peak at $36.1 \mathrm{eV}$ and a loss feature at $42 \mathrm{eV}$ indicating the presence of $\mathrm{WO}_{3}$, where oxidation state of $\mathrm{W}$ is +6 [38]. The analysis of Ti $2 \mathrm{p}$ spectra for all titanium containing catalysts was also performed and it shows the doublet for $2 \mathrm{p}$ with $2 \mathrm{p} 3 / 2$ at $458.1 \mathrm{eV}$ confirming the +4 oxidation state of titanium.

\subsection{Hydrotreating of Bitumen Derived Gas Oils}

The hydrotreating of LGO and HGO facilitated by $\mathrm{NiMo} / \gamma-\mathrm{Al}_{2} \mathrm{O}_{3}$ in fixed bed flow reactor operating at $9 \mathrm{MPa}, 370{ }^{\circ} \mathrm{C}$, LHSV $1.5 \mathrm{~h}^{-1}, 75 \mathrm{~mL} / \mathrm{min} \mathrm{H}_{2}$ for LGO and $9 \mathrm{MPa}, 390^{\circ} \mathrm{C}$, LHSV $1.0 \mathrm{~h}^{-1}$, $50 \mathrm{~mL} / \mathrm{min}_{2}$ for $\mathrm{HGO}$, significantly lowered the sulphur and nitrogen content. For HGO the sulphur content was lowered from 41,000 ppm to $2100 \mathrm{ppm}$ and nitrogen content dropped from $3900 \mathrm{ppm}$ to $1750 \mathrm{ppm}$, resulting in $94.8 \mathrm{wt} . \% \mathrm{~S}$ and $55.0 \mathrm{wt} . \% \mathrm{~N}$ removal. The LGO hydrotreating succeeded in lowering the sulphur content from $24,000 \mathrm{ppm}$ to $950 \mathrm{ppm}$ and nitrogen content from $1400 \mathrm{ppm}$ to $175 \mathrm{ppm}$, thus achieving $96.0 \mathrm{wt} . \% \mathrm{~S}$ and $87.5 \mathrm{wt} . \% \mathrm{~N}$ removal. The hydrotreated HGO and LGO were called as HDT-HGO and HDT-LGO, respectively and were further treated by oxidative desulfurization and denitrogenation process to achieve less than $500 \mathrm{ppm}$ in treated LGO and HGO.

\subsection{Oxidative Desulfurization and Denitrogenation}

The synthesized catalysts were tested for the oxidation of sulphur and nitrogen containing aromatic compounds present in hydrotreated HGO and LGO. The oxidation increases the polarity of organosulfur and nitrogen compounds and therefore, the oxidized sulphur and nitrogen compounds were then removed by adsorption or extraction. The oxidation of sulphur and nitrogen compounds by tert-butyl hydroperoxide is facilitated by the supported metal oxide catalyst. TBHP nucleophilically attacks the Mo in molybdenum oxide (and $\mathrm{W}$ in tungsten oxide), to form peroxymolybdate (peroxymetallic) complex. This complex activates the peroxy group to oxidize the sulphur present in organosulfur compounds. Thus, forming sulfoxide and regenerating molybdenum oxide. The molybdenum oxide again undergoes reaction with another TBHP molecule to form peroxymolybdate complex, which further oxidizes sulfoxide to sulfone (see Figure 7) and regenerate molybdenum oxide. Simple mechanism shown in Figure 7 is inspired from previous studies in literature [48-50]. The sulfoxides and sulfones were then separated out using adsorption or extraction due to increase in their polarity. The oxidation of nitrogen containing organic compounds such as quinoline does not necessarily oxidizes the nitrogen, however it is a complex reaction. Studies in literature [25] showed that the carbon with least electron density in the ring of organonitrogen compound is oxidized by peroxides and then followed by ring opening. Further oxidation will result in formation of various oxygenates of organonitrogen compounds, which can be then removed from gas oil via adsorption or extraction due to increase in polarity of oxygenated nitrogen compounds.

Three adsorbents including Activated carbon, Amberlyst 15 ion exchange resin and Amberlite IRA-400 ion exchange resin were tested to determine a suitable adsorbent for this work. Equal amount of each adsorbent was mixed with HDT-LGO and HDT-HGO in separate flasks to determine the adsorption capacity of each adsorbent for adsorbing sulphur and nitrogen compounds from hydrotreated gas oils. The results shown in Table 2 indicates that all adsorbents can remove 4-9 wt.\% sulphur. Activated carbon and Amberlite IRA-400 ion exchange resin were able to adsorb and remove 11-15 wt.\% nitrogen. However, the Amberlyst 15 ion exchange resin removed $25 \mathrm{wt} . \% \mathrm{~N}$ 
from HDT-HGO and $33 \mathrm{wt} . \% \mathrm{~N}$ from HDT-LGO. This could be due the attractive forces between basic nitrogen compounds and highly acidic Amberlyst 15 resin. Further, the adsorption followed by oxidation of hydrotreated gas oil was also carried out using above mentioned three adsorbents. Results shown in Table 2 suggests the effectiveness of activated carbon as adsorbent for the removal of oxygenated sulphur and nitrogen compounds. $\mathrm{Mo} / \gamma-\mathrm{Al}_{2} \mathrm{O}_{3}$ catalysed oxidation followed by adsorptive removal of oxygenates with activated carbon removed $32 \%$ and $44.9 \%$ sulphur from single stage oxidative desulfurization of HDT-HGO and HDT-LGO respectively, as against to less than $10 \%$ removal by ion exchange resins. Additionally, the nitrogen removal was also higher with activated carbon after single stage oxidative denitrogenation.

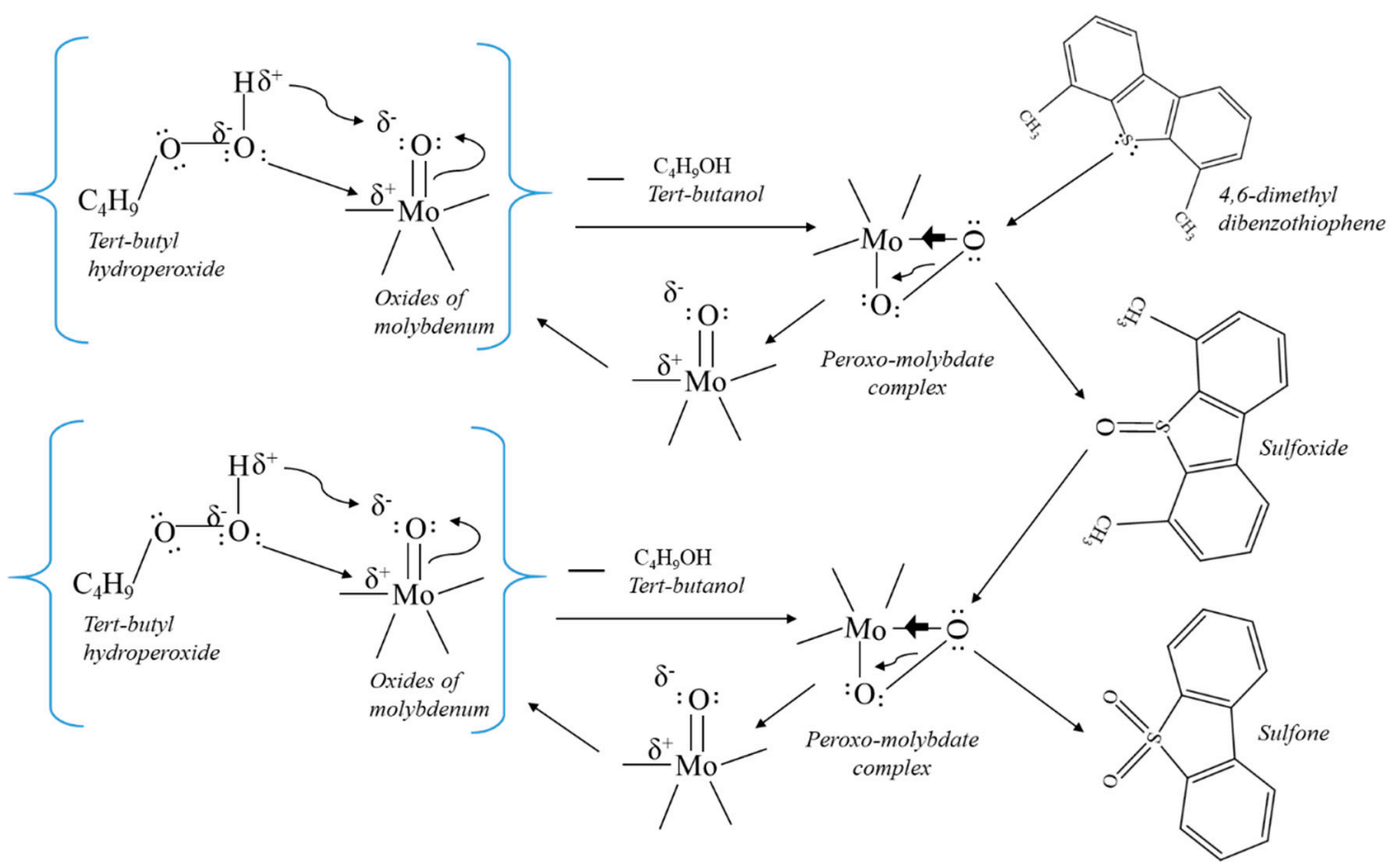

Figure 7. Simplistic mechanism for the oxidation of sulphur containing compounds via TPHP in presence of catalyst.

Table 2. Adsorption capacity of various adsorbents for sulphur and nitrogen compounds present in gas oil. (error $\pm 1 \%$ ).

\begin{tabular}{|c|c|c|c|c|c|}
\hline \multicolumn{3}{|c|}{ Adsorption Capacity (wt.\%) of Following Adsorbents $\rightarrow$} & \multirow{2}{*}{$\begin{array}{c}\begin{array}{c}\text { Activated } \\
\text { Carbon }\end{array} \\
5.1\end{array}$} & \multirow{2}{*}{$\begin{array}{c}\begin{array}{c}\text { Amberlyst 15, Ion } \\
\text { Exchange Resin }\end{array} \\
4.8\end{array}$} & \multirow{2}{*}{$\begin{array}{c}\text { Amberlite } \\
\text { IRA-400(CI), Ion } \\
\text { Exchange Resin } \\
4.3\end{array}$} \\
\hline \multirow{4}{*}{ HDT-HGO } & \multirow{2}{*}{ For hydrotreated gas oil } & $\% \mathrm{~S}$ removal & & & \\
\hline & & $\% \mathrm{~N}$ removal & 11.0 & 25.0 & 12.0 \\
\hline & \multirow{2}{*}{$\begin{array}{c}\text { After single state oxidative } \\
\text { desulfurization (catalyst: } \mathrm{Mo} / \gamma-\mathrm{Al}_{2} \mathrm{O}_{3} \text { ) }\end{array}$} & $\% \mathrm{~S}$ removal & 32.0 & 7.1 & 6.8 \\
\hline & & $\% \mathrm{~N}$ removal & 31.3 & 22.0 & 19.0 \\
\hline \multirow{4}{*}{ HDT-LGO } & \multirow{2}{*}{ For hydrotreated gas oil } & $\%$ S removal & 8.1 & 9.0 & 6.3 \\
\hline & & $\% \mathrm{~N}$ removal & 15.0 & 33.0 & 14.0 \\
\hline & \multirow{2}{*}{$\begin{array}{c}\text { After single state oxidative } \\
\text { desulfurization (catalyst: } \mathrm{Mo} / \gamma-\mathrm{Al}_{2} \mathrm{O}_{3} \text { ) }\end{array}$} & $\%$ S removal & 44.9 & 9.9 & 8.1 \\
\hline & & $\% \mathrm{~N}$ removal & 49.7 & 28.0 & 20.0 \\
\hline
\end{tabular}

Liquid-liquid extraction of oxidized sulphur and nitrogen compounds from oil phase was done with methanol. It was observed that methanol phase containing polar sulfoxides, sulfone and oxides of nitrogen compounds separates out easily from treated HDT-HGO. However, due to less difference between densities of HDT-LGO and methanol the separation was difficult and takes longer time. Nevertheless, for oxidized HDT-HGO and HDT-LGO the activated carbon could remove higher 
amount of oxidized sulphur and nitrogen compounds in comparison to extraction with methanol as shown in Tables 3 and 4 for oxidative desulfurization and denitrogenation of HDT-HGO and HDT-LGO. Therefore, in this this study activated carbon was used as adsorbent for further reactions with various catalysts.

Table 3. Oxidative desulfurization and denitrogenation of hydrotreated heavy gas oil. (error $\pm 4 \mathrm{ppm}$ ).

\begin{tabular}{|c|c|c|c|c|c|c|c|}
\hline \multicolumn{2}{|c|}{$\begin{array}{l}\mathrm{S} \text { conc. in HDT-HGO }=2100 \mathrm{ppm} . \mathrm{N} \\
\text { conc. in HDT-HGO }=1750 \mathrm{ppm} \text {. } \\
\text { Single-Stage ODS and ODN Using } \\
\text { Following Catalysts and TBHP }\end{array}$} & \multirow{2}{*}{$\begin{array}{c}\mathrm{Mo} / \gamma-\mathrm{Al}_{2} \mathrm{O}_{3} \\
1427\end{array}$} & \multirow{2}{*}{$\begin{array}{c}\mathrm{Mo} / \gamma-\mathrm{Al}_{2} \mathrm{O}_{3}-\mathrm{TiO}_{2} \\
1307\end{array}$} & \multirow{2}{*}{$\begin{array}{c}\mathbf{W} / \gamma-\mathrm{Al}_{2} \mathrm{O}_{3} \\
1612\end{array}$} & \multirow{2}{*}{$\frac{\mathrm{W} / \gamma-\mathrm{Al}_{\mathbf{2}} \mathrm{O}_{3}-\mathrm{TiO}_{2}}{1518}$} & \multirow{2}{*}{$\begin{array}{c}\mathrm{PMo} / \gamma-\mathrm{Al}_{2} \mathrm{O}_{3}-\mathrm{TiO}_{2} \\
1244\end{array}$} & \multirow{2}{*}{$\frac{\mathrm{MnPMo} / \gamma-\mathrm{Al}_{2} \mathrm{O}_{3}-\mathrm{TiO}_{2}}{1167}$} \\
\hline S conc. & $\begin{array}{l}\text { Adsorption using } \\
\text { activated carbon }\end{array}$ & & & & & & \\
\hline & $\begin{array}{l}\text { Solvent Extraction using } \\
\text { Methanol }\end{array}$ & 1508 & 1417 & 1729 & 1740 & - & - \\
\hline \multirow{2}{*}{$\begin{array}{l}\text { N conc. } \\
\text { (ppm) }\end{array}$} & $\begin{array}{l}\text { Adsorption using } \\
\text { activated carbon }\end{array}$ & 1203 & 1115 & 1405 & 1294 & 1037 & 938 \\
\hline & $\begin{array}{l}\text { Solvent Extraction using } \\
\text { Methanol }\end{array}$ & 1293 & 1208 & 1506 & 1412 & - & - \\
\hline \multirow{2}{*}{$\begin{array}{c}\% \text { removal } \\
\mathrm{S}\end{array}$} & $\begin{array}{l}\text { Adsorption using } \\
\text { activated carbon }\end{array}$ & 32.0 & 37.8 & 23.2 & 27.7 & 40.8 & 44.4 \\
\hline & $\begin{array}{l}\text { Solvent Extraction using } \\
\text { Methanol }\end{array}$ & 28.2 & 32.5 & 17.7 & 17.1 & - & - \\
\hline \multirow{2}{*}{$\begin{array}{l}\text { \% removal } \\
\mathrm{N}\end{array}$} & $\begin{array}{l}\text { Adsorption using } \\
\text { activated carbon }\end{array}$ & 31.3 & 36.3 & 19.7 & 26.1 & 40.7 & 46.4 \\
\hline & $\begin{array}{l}\text { Solvent Extraction using } \\
\text { Methanol }\end{array}$ & 26.1 & 31.0 & 13.9 & 19.3 & - & - \\
\hline
\end{tabular}

The purified gas oil after adsorption is then tested for sulphur and nitrogen content and the percentage desulfurization and denitrogenation was used as a measure to define the catalytic activity. Tables 3 and 4 show the data for oxidative desulfurization and denitrogenation using various catalysts. It was observed that the Mo containing catalysts performs better than $\mathrm{W}$ containing catalysts for both desulfurization and denitrogenation for HDT-HGO and HDT-LGO. Mo $/ \gamma-\mathrm{Al}_{2} \mathrm{O}_{3}$ catalyst showed $32 \%$ $\mathrm{S}$ and $31.3 \% \mathrm{~N}$ removal for HDT-HGO and $44.9 \% \mathrm{~S}$ and $49.7 \% \mathrm{~N}$ removal for HDT-LGO, whereas, the $\mathrm{W} / \gamma-\mathrm{Al}_{2} \mathrm{O}_{3}$ catalyst showed $23.2 \% \mathrm{~S}$ and $19.7 \% \mathrm{~N}$ removal for $\mathrm{HGO}$ and $41.7 \% \mathrm{~S}$ and $47.4 \% \mathrm{~N}$ removal for LGO. It should be noted that although the weight percentage removal of nitrogen is higher than percentage removal of sulphur for HDT-LGO but in terms of ppm sulphur removal is higher. The higher activity of molybdenum supported catalyst in comparison to tungsten supported catalyst could be attributed to the higher rate of activation of TBHP by molybdenum, which results in the formation of peroxometallic species leading to the oxidation of sulphur to sulfoxide and sulfone. This could be due to the stronger bonding between Mo $4 \mathrm{~d}$ orbital and peroxy oxygen $2 \mathrm{p}$ orbital during nucleophilic attack by TBHP on molybdenum oxide in comparison to bonding between $\mathrm{W} 5 \mathrm{~d}$ and $2 \mathrm{p}$ orbital.

The increase in desulfurization and denitrogenation activity on incorporation of titanium as shown in Tables 3 and 4 is due to its Lewis acid character. XRD analysis has confirmed the presence of anatase $\mathrm{TiO}_{2}$ and Ti $2 p$ XPS spectra confirmed +4 oxidation state of titanium, which indicates the Lewis acid character of titanium. Therefore, the electron deficient titania will further provide the site for nucleophilic attack by TBHP for the formation of peroxo-titanium complex [51]. This complex activates the oxidation of sulphur and nitrogen compounds. Thus, Ti increases ODS and ODN activity by $8-12 \%$.

Considering the promising activity of $\mathrm{Mo} / \gamma-\mathrm{Al}_{2} \mathrm{O}_{3}-\mathrm{TiO}_{2}$ catalyst further promotion by phosphorus $(\mathrm{P})$ and manganese $(\mathrm{Mn})$ was studied for $\mathrm{Mo} / \gamma-\mathrm{Al}_{2} \mathrm{O}_{3}-\mathrm{TiO}_{2}$ catalyst. The addition of $\mathrm{P}$ as $\mathrm{PO}_{4}{ }^{3-}$ makes molybdenum more electrophilic. Thereby boosting the rate of reaction of peroxides (TBHP) with Mo, which results in the creation of active species for oxidation of sulphur and nitrogen compounds. The results showing increase in desulfurization and denitrogenation from $37.8 \%$ to $40.8 \%$ and $36.3 \%$ to $40.7 \%$, respectively, on addition of P are presented in Table 3 for HDT-HGO. Similar increase in activity was observed for HDT-LGO as shown in Table 4. 
Table 4. Oxidative desulfurization and denitrogenation of hydrotreated light gas oil. (error $\pm 4 \mathrm{ppm}$ ).

\begin{tabular}{|c|c|c|c|c|c|c|c|}
\hline \multicolumn{2}{|c|}{$\begin{array}{l}\mathrm{S} \text { conc. in HDT-LGO }=950 \mathrm{ppm} . \mathrm{N} \\
\text { conc. in HDT-LGO }=175 \mathrm{ppm} . \\
\text { Single-Stage ODS and ODN Using } \\
\text { Following Catalysts and TBHP }\end{array}$} & \multirow{2}{*}{$\begin{array}{c}\mathrm{Mo} / \gamma-\mathrm{Al}_{2} \mathrm{O}_{3} \\
523\end{array}$} & \multirow{2}{*}{$\begin{array}{c}\mathrm{Mo} / \gamma-\mathrm{Al}_{2} \mathrm{O}_{3}-\mathrm{TiO}_{2} \\
487\end{array}$} & \multirow{2}{*}{$\begin{array}{c}\mathrm{W} / \gamma-\mathrm{Al}_{2} \mathrm{O}_{3} \\
554\end{array}$} & \multirow{2}{*}{$\begin{array}{c}\mathrm{W} / \gamma-\mathrm{Al}_{2} \mathrm{O}_{3}-\mathrm{TiO}_{2} \\
508\end{array}$} & \multirow{2}{*}{$\begin{array}{c}\mathrm{PMo} / \gamma-\mathrm{Al}_{2} \mathrm{O}_{3}-\mathrm{TiO}_{2} \\
462\end{array}$} & \multirow{2}{*}{$\frac{\mathrm{MnPMo} / \gamma-\mathrm{Al}_{2} \mathrm{O}_{3}-\mathrm{TiO}_{2}}{428}$} \\
\hline $\mathrm{S}$ conc. & $\begin{array}{l}\text { Adsorption using } \\
\text { activated carbon }\end{array}$ & & & & & & \\
\hline & $\begin{array}{c}\text { Solvent Extraction using } \\
\text { Methanol }\end{array}$ & 570 & 540 & 582 & 541 & - & - \\
\hline \multirow{2}{*}{$\begin{array}{l}\text { N conc. } \\
\text { (ppm) }\end{array}$} & $\begin{array}{l}\text { Adsorption using } \\
\text { activated carbon }\end{array}$ & 88 & 76 & 92 & 82 & 57 & 40 \\
\hline & $\begin{array}{c}\text { Solvent Extraction using } \\
\text { Methanol }\end{array}$ & 103 & 85 & 115 & 101 & - & - \\
\hline \multirow{2}{*}{$\begin{array}{c}\text { \% removal } \\
\mathrm{S}\end{array}$} & $\begin{array}{l}\text { Adsorption using } \\
\text { activated carbon }\end{array}$ & 44.9 & 48.7 & 41.7 & 46.5 & 51.4 & 54.9 \\
\hline & $\begin{array}{c}\text { Solvent Extraction using } \\
\text { Methanol }\end{array}$ & 40.0 & 43.2 & 38.7 & 43.1 & - & - \\
\hline \multirow{2}{*}{$\begin{array}{l}\% \text { removal } \\
\mathrm{N}\end{array}$} & $\begin{array}{l}\text { Adsorption using } \\
\text { activated carbon }\end{array}$ & 49.7 & 56.6 & 47.4 & 53.1 & 67.4 & 77.1 \\
\hline & $\begin{array}{c}\text { Solvent Extraction using } \\
\text { Methanol }\end{array}$ & 41.1 & 51.4 & 34.3 & 42.3 & - & - \\
\hline
\end{tabular}

The catalyst $\mathrm{MnPMo} / \gamma-\mathrm{Al}_{2} \mathrm{O}_{3}-\mathrm{TiO}_{2}$ further increased the desulfurization and denitrogenation activity from $40.8 \%$ to $44.4 \%$ and $40.7 \%$ to $46.4 \%$, respectively, with reference to activity shown by $\mathrm{PMo} / \gamma-\mathrm{Al}_{2} \mathrm{O}_{3}-\mathrm{TiO}_{2}$ catalyst for HDT-HGO. The increase in activity could be assigned to the oxidizing or electron-accepting tendency of manganese. Mn 3s and Mn 2p XPS analysis has confirmed that manganese is in +2 oxidation state, indicating the presence of $\mathrm{MnO}$ and $\mathrm{MnMoO}_{4}$. However, FTIR analysis and $\mathrm{XRD}$ analysis for $\mathrm{MnPMo} / \gamma-\mathrm{Al}_{2} \mathrm{O}_{3}-\mathrm{TiO}_{2}$ catalyst have confirmed the polymolybdate species present in $\mathrm{MnMoO}_{4}$ form. Therefore, the manganese in $\mathrm{MnMoO}_{4}$, will make Mo more electrophilic $\left(-\mathrm{Mo}^{\delta+}=\mathrm{O}\right)$. Hence, this increases the rate of reaction of TBHP with catalyst, which eventually increase the ODS and ODN activity. Similar increase in activity was observed for HDT-LGO as shown in Table 4.

Single stage oxidative desulfurization has lowered the sulphur content of HDT-HGO from $2100 \mathrm{ppm}$ to $1167 \mathrm{ppm}$ using $\mathrm{MnPMo} / \gamma-\mathrm{Al}_{2} \mathrm{O}_{3}-\mathrm{TiO}_{2}$ catalyst. However, to remove sulphur down to less than $500 \mathrm{ppm}$, multistage oxidation process was employed. To perform multistage oxidation, large amount of product from first stage ODS is required in order to account for the samples, which will be extracted after each stage for analysis. The spent catalyst from single stage process was utilized to oxidize another fresh batch of HDT-HGO to generate more product oil from first stage oxidative desulfurization process. It was observed that the sulphur removal efficiency decline from $44.4 \%$ to $40.1 \%$ on reusing the catalyst. The decrease in sulphur removal efficiency could be due to the active site inhibition by bulky heteroatomic molecules present in the HGO or might be due to the leaching of the fraction of Mo. However, $4.3 \%$ decline in sulphur removal or $9.7 \%$ decline in catalyst activity is not a clear affirmation of leaching due to other possible factors. Therefore, considering the scope of this paper, reusability, metal leaching and catalyst stability studies were not conducted and fresh catalyst was used to generate more product oil from stage 1 ODS.

Table 5 shows that after 3 stage ODS the sulphur in treated HGO was lowered to $478 \mathrm{ppm}$, accounting to $77.2 \%$ sulphur removal. It was also observed that between stage 2 and stage 3 of ODS process only $87 \mathrm{ppm}(\sim 4 \%)$ sulphur was removed. Therefore, increasing the number of ODS stages beyond $3^{\text {rd }}$ stage will not be able to further lower the sulphur concentration significantly. Interestingly, the denitrogenation with multistage oxidation process was more effective than desulfurization. The nitrogen content was lowered from 1750 to 206 ppm ( 88\% nitrogen removal) for HDT-HGO. Nitrogen is a well-known poison to many downstream processing catalysts, therefore, the decrease in nitrogen content will benefit the downstream processing of treated HGO and LGO. 
Table 5. Multistage ODS and ODN of hydrotreated gas oils. (error $\pm 4 \mathrm{ppm}$ ).

\begin{tabular}{ccccc}
\hline $\begin{array}{c}\text { ODS and ODN Stages with } \mathbf{M n P M o} / \gamma-\mathrm{Al}_{\mathbf{2}} \mathrm{O}_{\mathbf{3}}-\mathrm{TiO}_{\mathbf{2}} \\
\text { Catalyst, TBHP and Activated Carbon }\end{array}$ & Stage 1 & Stage 2 & Stage 3 \\
\hline & S conc. (ppm) & 1167 & 565 & 478 \\
$\mathrm{HDT}-\mathrm{HGO}(\mathrm{S}=2100$ & Cumulative \% S removal & 44.4 & 73.1 & 77.2 \\
ppm; N = 1750 ppm) & N conc. (ppm) & 938 & 261 & 206 \\
& Cumulative \% N removal & 46.4 & 85.1 & 88.2 \\
\hline & S conc. (ppm) & 428 & 394 & 354 \\
HDT-LGO (S = 950 & Cumulative \% S removal & 54.9 & 58.5 & 62.7 \\
ppm; N = 175 ppm) & N conc. (ppm) & 40 & 30 & 30 \\
& Cumulative \% N removal & 77.1 & 82.9 & 82.9 \\
\hline
\end{tabular}

Three-stage oxidative desulfurization and denitrogenation was also carried out for HDT-LGO and the results are presented in Table 5. After first stage the sulphur and nitrogen contents were lowered to $428 \mathrm{ppm}$ and $40 \mathrm{ppm}$ respectively. It was observed that the increase in percentage sulphur and nitrogen removal was not significant after two-stage and three-stage processes. The total $\mathrm{S}$ and $\mathrm{N}$ removal after third stage is $62.7 \%$ and $82.9 \%$ in comparison to $54.9 \%$ and $77.1 \%$ after single stage ODS and ODN, respectively. Therefore, the combination of hydrotreating and oxidative desulfurization-denitrogenation can lower the sulphur content from 41,000 ppm to $480 \mathrm{ppm}$ and nitrogen content from $3900 \mathrm{ppm}$ to $210 \mathrm{ppm}$ for HGO. In future, this study can serve as a basis to design the process at commercial scale, which can enable oil-sands derived gas oils to stay competitive to conventional crude oil.

\section{Experimental}

\subsection{Materials}

Titanium isopropoxide, ammonium dihydrogen phosphate, Ammonium heptamolybdate tertrahydrate, Manganese nitrate hexahydrate, tert-butylhydroperoxide (TBHP) (70 v/v\%), Ammonium metatungstate hydrate, were purchased from Sigma Aldrich, Edmonton, Canada. Activated carbon was provided by Norit, Canada. Amberlyst 15 ion exchange resin and Amberlite IRA-400 ion exchange resin were purchased from Alfa Aesar, USA. $\gamma-\mathrm{Al}_{2} \mathrm{O}_{3}$ and methanol was purchased from Fischer-Scientific, Toronto, Canada.

\subsection{Catalyst Synthesis}

All metals were impregnated using incipient wetness method. $\mathrm{Al}_{2} \mathrm{O}_{3}-\mathrm{TiO}_{2}$ material was synthesized by impregnating the solution of titanium isopropoxide and ethanol on $\gamma-\mathrm{Al}_{2} \mathrm{O}_{3}$ to obtain 10 wt. $\% \mathrm{TiO}_{2}$ in $\mathrm{Al}_{2} \mathrm{O}_{3}-\mathrm{TiO}_{2} .15 \mathrm{wt} . \% \mathrm{~W}$ and $15 \mathrm{wt} . \%$ Mo were impregnated on $\boldsymbol{\gamma}-\mathrm{Al}_{2} \mathrm{O}_{3}$ and $\mathrm{Al}_{2} \mathrm{O}_{3}-\mathrm{TiO}_{2}$ materials using ammonium metatungstate hydrate and ammonium heptamolybdate tertrahydrate as precursors for $\mathrm{W}$ and Mo, respectively. The materials were dried overnight at $100{ }^{\circ} \mathrm{C}$ and then calcined at $550{ }^{\circ} \mathrm{C}$ for $6 \mathrm{~h}$. The resulting materials were named as $\mathrm{Mo} / \gamma-\mathrm{Al}_{2} \mathrm{O}_{3}, \mathrm{Mo} / \gamma-\mathrm{Al}_{2} \mathrm{O}_{3}-\mathrm{TiO}_{2}$, $\mathrm{W} / \boldsymbol{\gamma}-\mathrm{Al}_{2} \mathrm{O}_{3}$ and $\mathrm{W} / \boldsymbol{\gamma}-\mathrm{Al}_{2} \mathrm{O}_{3}-\mathrm{TiO}_{2}$. Further, 2 wt. $\%$ phosphorus was impregnated to $\mathrm{Mo} / \gamma-\mathrm{Al}_{2} \mathrm{O}_{3}-\mathrm{TiO}_{2}$ using ammonium dihydrogen phosphate as precursor. This was followed by drying and calcination at $400{ }^{\circ} \mathrm{C}$ for $4 \mathrm{~h}$ to obtain $\mathrm{PMo} / \gamma-\mathrm{Al}_{2} \mathrm{O}_{3}-\mathrm{TiO}_{2}$ catalyst. Manganese nitrate hexahydrate was used as a precursor for $\mathrm{Mn}$ and it was wet impregnated on $\mathrm{PMo} / \gamma-\mathrm{Al}_{2} \mathrm{O}_{3}-\mathrm{TiO}_{2}$ to obtain 2 wt. $\% \mathrm{Mn}$ in $\mathrm{MnPMo} / \gamma-\mathrm{Al}_{2} \mathrm{O}_{3}-\mathrm{TiO}_{2}$ catalyst. The catalyst containing $13 \mathrm{wt} . \% \mathrm{Mo}$ and $3 \mathrm{wt} . \% \mathrm{Ni}$ supported on $\gamma-\mathrm{Al}_{2} \mathrm{O}_{3}$ was also synthesized using sequential wetness impregnation method and named as $\mathrm{NiMo} / \gamma-\mathrm{Al}_{2} \mathrm{O}_{3}$. 


\subsection{Material Characterization}

All materials were characterized in oxide state. Micrometrics ASAP2020 instrument was used to determine the textural properties. The Brunauer-Emmett-Teller (BET) method was used to determine the surface area and Barrett-Joyner-Halenda $(\mathrm{BJH})$ method was used to calculate the pore diameter and pore volume. The wide angle $\left(20^{\circ}\right.$ to $\left.80^{\circ}\right) \mathrm{X}$-ray diffractograms for powder samples were obtained using Bruker Advance D8 series II equipment having $\mathrm{Cu} \mathrm{K} \alpha$ radiation. The FTIR analysis for the materials was performed using PerkinElmer Spectrum GX instrument. The details on the sample preparation and method of analysis for XRD, FTIR and BET are mentioned in our previous work [52]. The X-ray photoelectron spectroscopy (XPS) analysis was performed to determine the oxidation state of active metals. The XPS spectra for catalysts were collected using Kratos Axis SUPRA XPS instrument equipped with monochromatic $\mathrm{Al} \mathrm{K} \alpha \mathrm{X}$-ray source. This instrument is located at Saskatchewan Structural Sciences Centre, University of Saskatchewan, Canada. The XPS data were fitted using CasaXPS software.

\subsection{Hydrotreating Experiment}

The fixed bed flow reactor system was used to perform hydrotreating reactions for HGO and LGO. The physical properties of HGO and LGO are mentioned in Table 6. The reaction setup consists of a liquid feed pump, $\mathrm{H}_{2}$ and $\mathrm{He}$ gas inlet lines via mass flow controllers, tube type fixed bed reactor heated by furnace, back pressure regulator, $\mathrm{NH}_{3}$ scrubber and gas-liquid separator to collect the hydrotreated product followed by nitrogen stripping. The schematic and details of the setup are mentioned in our previous work [52]. $5 \mathrm{~g}$ of $\mathrm{NiMo} / \gamma-\mathrm{Al}_{2} \mathrm{O}_{3}$ catalyst was diluted with $\mathrm{SiC}$ ( 90 mesh size) and loaded in the reactor. The catalyst was sulphided by pumping $5 \mathrm{~mL} / \mathrm{h}$ of $2.9 \mathrm{vol} \%$ butanethiol solution (in transformer oil) through the catalyst bed for $48 \mathrm{hrs}$. The first $24 \mathrm{~h}$ sulphidation was performed at $190{ }^{\circ} \mathrm{C}$ and then the temperature was raised to $340^{\circ} \mathrm{C}$ and maintained for next $24 \mathrm{~h}$. The reactor was pressurized to $9 \mathrm{MPa}$ with helium prior to start of sulphidation. The entire sulphidation process was carried out at $50 \mathrm{~mL} / \mathrm{min}$ of hydrogen flow.

Table 6. Physical properties of heavy gas oil and light gas oil.

\begin{tabular}{ccc}
\hline Properties & Heavy Gas Oil & Light Gas Oil \\
\hline Sulphur (wt.\%) & 4.1 & 2.4 \\
Nitrogen (wt. $\%)$ & 0.39 & 0.14 \\
Density (g/mL) & 0.96 & 0.89 \\
Aromatic content $(\%)$ & 42.0 & 30 \\
Boiling range $\left({ }^{\circ} \mathrm{C}\right)$ & $\mathrm{wt} . \%$ & $\mathrm{wt} . \%$ \\
Initial boiling point-300 & 3.0 & 46.4 \\
301-400 & 20.8 & 42.7 \\
401-500 & 54.0 & 10.9 \\
501-600 & 20.2 & - \\
600-Final boiling point & 2.0 & - \\
\hline
\end{tabular}

The liquid feed was switched to gas oil (HGO or LGO) after sulphidation and the reaction temperature was increased to $370{ }^{\circ} \mathrm{C}$ for LGO and $390{ }^{\circ} \mathrm{C}$ for HGO. The gas oil feed rate was maintained at $5 \mathrm{~mL} / \mathrm{h}$ and $7.5 \mathrm{~mL} / \mathrm{h}$ for $\mathrm{HGO}$ and LGO, respectively. The $\mathrm{H}_{2}$ feed rate was maintained at $50 \mathrm{~mL} / \mathrm{h}$ for HGO and $75 \mathrm{~mL} / \mathrm{h}$ for LGO. The hydrotreated oil was collected every $24 \mathrm{~h}$ and analysed for sulphur and nitrogen content. The constant conversion was observed from day 5 to day 12 and then the reactor was shut down. Therefore, the hydrotreated oil product from day 6-12 was mixed to obtain a big batch of hydrotreated gas oil, hereafter called as HDT-HGO and HDT-LGO. Hydrotreating of LGO and HGO was done with fresh catalyst in the same experimental set-up. The Antek 9000 N/S analyser was used to determine the nitrogen and sulphur content in liquid samples. ASTM D4629 method using combustion/chemiluminescence technique was adopted to determine the total nitrogen content of the liquid product and the ASTM D5463 method using combustion/fluorescence technique was deployed 
for measuring sulphur content. The details on catalyst loading procedure and sulphidation procedure are mentioned in our previous works [52].

\subsection{Experimental Procedure for Oxidative Desulfurization and Denitrogenation}

$20 \mathrm{ml}$ of HDT-HGO was taken in a round bottom flask and $1 \mathrm{~g}$ catalyst was added to it. To this mixture $20 \mathrm{ml}$ of TBHP $(70 \% v / v)$ was added as an oxidizer and stirred at $400 \mathrm{rpm}$ at $90{ }^{\circ} \mathrm{C}$ under reflux for $15 \mathrm{~h}$. The 1:1 volume ratio of TBHP and HDT-HGO was used for screening experiments considering the complex nature of bitumen derived heavy gas oil. This makes molar ratio of TBHP to sulphur equal to 110 and TBHP to nitrogen molar ratio equal to 58, which is quite high. The Metal (Mo) to sulphur molar ratio is 1.2. Further, handling equal amount of TBHP and gas oil in existing refineries will be a concern. However, this lab scale experiment was performed for the proof of concept and further optimization studies on the amount of oxidant, catalyst, oil, stirring speed and temperature can help to determine the techno-economical and logistical viability of this process integration with existing refineries. The reaction was cooled down to room temperature and then filtered to recover the solid catalyst. The catalysts tested for this reaction are: $\mathrm{Mo} / \gamma-\mathrm{Al}_{2} \mathrm{O}_{3}, \mathrm{Mo} / \gamma-\mathrm{Al}_{2} \mathrm{O}_{3}-\mathrm{TiO}_{2}, \mathrm{~W} / \boldsymbol{\gamma}-\mathrm{Al}_{2} \mathrm{O}_{3}$ and $\mathrm{W} / \gamma-\mathrm{Al}_{2} \mathrm{O}_{3}-\mathrm{TiO}_{2}$. $\mathrm{PMo} / \gamma-\mathrm{Al}_{2} \mathrm{O}_{3}-\mathrm{TiO}_{2}$ and $\mathrm{MnPMo} / \gamma-\mathrm{Al}_{2} \mathrm{O}_{3}-\mathrm{TiO}_{2}$. The reaction products were phase separated due to the difference in the density of oil phase and water phase. The oil phase was collected and water washed to remove dissolved butanol, which is the by-product of oxidation of sulphur and nitrogen compounds by TBHP.

The oxidized sulphur compounds known as sulfones and sulfoxides and oxides of aromatic nitrogen compounds were than extracted from the oil phase using adsorption or solvent extraction. Activated carbon was used as an adsorbent. In a typical experiment, $1 \mathrm{~g}$ of activated carbon was mixed with $20 \mathrm{~mL}$ of oil for $12 \mathrm{~h}$ at room temperature. The mixture was then filtered to separate the solids and the resultant liquid was analysed to determine total $\mathrm{S}$ and $\mathrm{N}$ content. The type and amount of oxidized sulphur and nitrogen compounds were not determined in this work due to the complex composition of heavy gas oil. Therefore, the total $\mathrm{S}$ and $\mathrm{N}$ content in product was used as a basis to define the catalyst activity. The liquid was again treated with TBHP in presence of fresh catalyst followed by adsorption with activated carbon to perform double stage adsorptive extraction, when required. Similar procedure was followed to perform multi-stage ODS and ODN.

The solvent extraction process was also tested to extract the sulfones, sulfoxides and oxides of organonitrogen compounds from the oil phase collected after oxidation with TBHP. $10 \mathrm{~mL}$ methanol was mixed with $20 \mathrm{~mL}$ oil and allowed to settle for $4 \mathrm{~h}$ at room temperature. The mixture was phase separated to obtain desulfurized and denitrogenated oil, which was then tested to determine the sulphur and nitrogen content. Similar procedure was followed to perform oxidative desulfurization and denitrogenation on HDT-LGO.

\section{Conclusions}

Highly efficient upgrading of oil-sands bitumen derived heavy gas oil ( 41,000 ppm sulphur, $3900 \mathrm{ppm}$ nitrogen) and light gas oil ( 24,000 ppm sulphur, $1400 \mathrm{ppm}$ nitrogen) is required to generate synthetic crude, which can compete with conventional crude oil. Therefore, in this work the combination of hydrotreating, oxidative desulfurization (ODS) and oxidative denitrogenation (ODN) was performed to achieve less than 500 ppm sulphur in LGO and HGO. The synthetic crude produced using treated HGO and LGO will be highly competitive and easily processed in existing refineries to produce various petroleum fractions including diesel fuel with less than $15 \mathrm{ppm}$ sulphur. The hydrotreating of gas oils was carried out in a fixed bed flow reactor operating at typical industrial conditions of $370-390{ }^{\circ} \mathrm{C}, 9 \mathrm{MPa}, 1-1.5 \mathrm{~h}^{-1}$ space velocity and $600: 1 \mathrm{H}_{2}$ to oil ratio. NiMo $/ \gamma-\mathrm{Al}_{2} \mathrm{O}_{3}$ was used as a catalyst. Hydrotreating resulted in lowering the sulphur and nitrogen content to 2100 ppm and 1750 ppm for HGO and 950 ppm and 175 ppm for LGO, respectively.

Various catalysts including $\mathrm{Mo} / \gamma-\mathrm{Al}_{2} \mathrm{O}_{3}, \mathrm{Mo} / \gamma-\mathrm{Al}_{2} \mathrm{O}_{3}-\mathrm{TiO}_{2}, \mathrm{~W} / \gamma-\mathrm{Al}_{2} \mathrm{O}_{3}, \mathrm{~W} / \gamma-\mathrm{Al}_{2} \mathrm{O}_{3}-\mathrm{TiO}_{2}$, $\mathrm{PMo} / \gamma-\mathrm{Al}_{2} \mathrm{O}_{3}-\mathrm{TiO}_{2}$ and $\mathrm{MnPMo} / \gamma-\mathrm{Al}_{2} \mathrm{O}_{3}-\mathrm{TiO}_{2}$ were synthesized and characterized using $\mathrm{X}$-ray 
diffractions, $\mathrm{N}_{2}$ adsorption-desorption, FTIR and XPS. All catalysts were tested for the oxidation of sulphur and nitrogen compounds present in gas oil using tert-butyl hydroperoxide (TBHP). The removal of oxides of sulphur and nitrogen compounds was carried out using adsorption and extraction. Methanol was used as solvent for liquid-liquid extraction, however, the minimal difference in densities of hydrotreated LGO and methanol possess challenge in separation and longer settling time was required. Among activated carbon and ion-exchange resins, the higher adsorption capacity for polar oxidized sulphur and nitrogen aromatic compounds was shown by activated carbon. The sulphur and nitrogen removal were higher with activated carbon in comparison to methanol. The catalytic activity measured in terms of percent sulphur and nitrogen removal was related to the catalyst characterization. XPS analysis has confirmed the oxidation state of metals such as Mo, Ti, Mn, P and $\mathrm{W}$, which helped in identifying the catalyst structure and relate it to the metal oxide structures as indicated by XRD and FTIR analysis. Mo supported catalyst outperformed the W supported catalyst due to stronger interaction between $2 \mathrm{p} \mathrm{O}$ (TBHP) and $4 \mathrm{~d}$ Mo orbitals in contrast to bonding between $5 \mathrm{~d} \mathrm{~W}$ and $2 \mathrm{p} \mathrm{O}$ orbitals. The Ti acts as an additional site for TBHP activation, which caused oxidation of sulphur and nitrogen containing compounds. $\mathrm{P}$ and $\mathrm{Mn}$ in $\mathrm{MnPMo} / \gamma-\mathrm{Al}_{2} \mathrm{O}_{3}-\mathrm{TiO}_{2}$ catalyst makes molybdenum more electrophilic, thereby promoting the nucleophilic attack by TBHP, thus facilitating oxidation. Hence, the catalyst $\mathrm{MnPMo} / \gamma-\mathrm{Al}_{2} \mathrm{O}_{3}-\mathrm{TiO}_{2}$ performed best among the series tested and removed $44.4 \mathrm{wt} . \%$ sulphur and $46.4 \mathrm{wt} . \%$ nitrogen from hydrotreated $\mathrm{HGO}$ and $54.9 \mathrm{wt} . \%$ sulphur and $77.1 \mathrm{wt} . \%$ nitrogen from hydrotreated LGO. Further three stage ODS and ODN process was performed using $\mathrm{MnPMo} / \gamma-\mathrm{Al}_{2} \mathrm{O}_{3}-\mathrm{TiO}_{2}$ catalyst. Thus, the integration of hydrotreating, oxidative desulfurization and oxidative denitrogenation lowered the sulphur and nitrogen content to $478 \mathrm{ppm}$ ( $\sim 98.8 \%$ removal) and $206 \mathrm{ppm}(\sim 94.7 \%$ removal), respectively, in HGO and $354 \mathrm{ppm}(\sim 98.5 \%$ removal) and $30 \mathrm{ppm}(\sim 97.8 \%$ removal), respectively in LGO. The decrease in nitrogen content is beneficial for the downstream processing of gas oils because nitrogen acts as a poison to various catalysts. Therefore, the combination of oxidative desulfurization and denitrogenation with hydrotreating is a promising methodology to improve the quality of synthetic crude derived from oil sands bitumen and keeping them competitive with respect to conventional petroleum crude oil.

Author Contributions: Conceptualization, S.B. and A.K.D.; Methodology, S.B. and G.K.; Validation, A.K.D. and Y.Z.; Formal Analysis, S.B., P.M. and G.K.; Writing-Original Draft Preparation, S.B.; Writing-Review \& Editing, P.M.; Supervision, Y.Z. and A.K.D.; Project Administration, A.K.D.; Funding Acquisition, Y.Z.

Funding: This research received no private funding.

Acknowledgments: The authors acknowledge financial assistance from NSERC and are thankful to Syncrude Canada ltd. for providing heavy and light gas oils. The authors are also thankful to Saskatchewan Structural Sciences Centre for the XPS analysis.

Conflicts of Interest: The authors declare no conflict of interest.

\section{References}

1. Sahoo, K. Sustainable Design and Simulation of Multi-Feedstock Bioenergy Supply Chain. Ph.D. Thesis, University of Georgia, Athens, Georgia, USA 2017.

2. Badoga, S.; Ganesan, A.; Dalai, A.K.; Chand, S. Effect of synthesis technique on the activity of CoNiMo tri-metallic catalyst for hydrotreating of heavy gas oil. Catal. Today 2017, 291, 160-171. [CrossRef]

3. Li, H.; Han, X.; Huang, H.; Wang, Y.; Zhao, L.; Cao, L.; Shen, B.; Gao, J.; Xu, C. Competitive adsorption desulfurization performance over K-Doped NiY zeolite. J. Colloid Interface Sci. 2016, 483, 102-108. [CrossRef]

4. Li, Y.X.; Jiang, W.J.; Tan, P.; Liu, X.Q.; Zhang, D.Y.; Sun, L.B. What matters to the adsorptive desulfurization performance of metal-Organic frameworks? J. Phys. Chem. C 2015, 119, 21969-21977. [CrossRef]

5. Saleh, T.A.; Sulaiman, K.O.; AL-Hammadi, S.A.; Dafalla, H.; Danmaliki, G.I. Adsorptive desulfurization of thiophene, benzothiophene and dibenzothiophene over activated carbon manganese oxide nanocomposite: with column system evaluation. J. Clean. Prod. 2017, 154, 401-412. [CrossRef] 
6. Ganiyu, S.A.; Ajumobi, O.O.; Lateef, S.A.; Sulaiman, K.O.; Bakare, I.A.; Qamaruddin, M.; Alhooshani, K. Boron-doped activated carbon as efficient and selective adsorbent for ultra-deep desulfurization of 4,6-dimethyldibenzothiophene. Chem. Eng. J. 2017, 321, 651-661. [CrossRef]

7. Srivastav, A.; Srivastava, V.C. Adsorptive desulfurization by activated alumina. J. Hazard. Mater. 2009, 170, 1133-1140. [CrossRef]

8. Seredych, M.; Bandosz, T.J. Adsorption of dibenzothiophenes on nanoporous carbons: Identification of specific adsorption sites governing capacity and selectivity. Energy Fuels 2010, 24, 3352-3360. [CrossRef]

9. McKinley, S.G.; Angelici, R.J. Deep desulfurization by selective adsorption of dibenzothiophenes on $\mathrm{Ag}^{+} / \mathrm{SBA}-15$ and $\mathrm{Ag}^{+} / \mathrm{SiO}_{2}$. Chem. Commun. 2003, 2620-2621. [CrossRef]

10. Zubaidi, I.A.; Darwish, N.N.; Sayed, Y.E.; Shareefdeen, Z.; Sara, Z. Adsorptive Desulfurization of Commercial Diesel oil Using Granular Activated Charcoal. Int. J. Adv. Chem. Eng. Biol. Sci. 2015, 2, 15-18.

11. Campos-Martin, J.M.; Capel-Sanchez, M.C.; Perez-Presas, P.; Fierro, J.L.G. Oxidative processes of desulfurization of liquid fuels. J. Chem. Technol. Biotechnol. 2010, 85, 879-890. [CrossRef]

12. Khalfalla, H.A. Modelling and Optimization of oxidative Desulphurization Process for Model Sulphur Compounds and Heavy Has Oil. Ph.D. Thesis, University of Bradford, Bradford, UK, 2009.

13. Jiang, Z.; Lu, H.; Zhang, Y.; Li, C. Oxidative Desulfurization of Fuel Oils. Chin. J. Catal. 2011, 32, 707-715. [CrossRef]

14. Bunthid, D.; Prasassarakich, P.; Hinchiranan, N. Oxidative desulfurization of tire pyrolysis naphtha in formic acid/H 2O2/pyrolysis char system. Fuel 2010, 89, 2617-2622. [CrossRef]

15. Ahmad, S.; Ahmad, M.; Naeem, K.; Humayun, M.; Sebt-E-Zaeem, S.; Faheem, F. Oxidative desulfurization of tire pyrolysis oil. Chem. Ind. Chem. Eng. Q. 2016, 22, 249-254. [CrossRef]

16. Palaić, N.; Sertić-bionda, K.; Margeta, D.; Podolski, Š. Oxidative Desulphurization of Diesel Fuels. Chem. Biochem. Eng. Q. 2015, 29, 323-327. [CrossRef]

17. Fattahi, A.M.; Omidkhah, M.R.; Moghaddam, A.Z.; Akbari, A. Synthesis and Characterization of Co-Mo $/ \gamma$-Al2O3 New Catalyst for Oxidative Desulfurization (ODS) of Model Diesel Fuel. Pet. Coal 2014, 56, 442-447.

18. Chica, A.; Corma, A.; Dómine, M.E. Catalytic oxidative desulfurization (ODS) of diesel fuel on a continuous fixed-bed reactor. J. Catal. 2006, 242, 299-308. [CrossRef]

19. Gatan, R.; Barger, P.; Gembicki, V.; Cavanna, A.; Molinari, D. Oxidative desulfurization: A new technology for ULSD. ACS Div. Fuel Chem. Prepr. 2004, 49, 577-579.

20. Leng, K.; Sun, Y.; Zhang, X.; Yu, M.; Xu, W. Ti-modified hierarchical mordenite as highly active catalyst for oxidative desulfurization of dibenzothiophene. Fuel 2016, 174, 9-16. [CrossRef]

21. Lorençon, E.; Alves, D.C.B.; Krambrock, K.; Ávila, E.S.; Resende, R.R.; Ferlauto, A.S.; Lago, R.M. Oxidative desulfurization of dibenzothiophene over titanate nanotubes. Fuel 2014, 132, 53-61. [CrossRef]

22. Tian, Y.; Wang, G.; Long, J.; Cui, J.; Jin, W.; Zeng, D. Ultra-deep oxidative desulfurization of fuel with $\mathrm{H} 2 \mathrm{O} 2$ catalyzed by phosphomolybdic acid supported on silica. Chin. J. Catal. 2016, 37, 2098-2105. [CrossRef]

23. García-Gutiérrez, J.L.; Laredo, G.C.; García-Gutiérrez, P.; Jiménez-Cruz, F. Oxidative desulfurization of diesel using promising heterogeneous tungsten catalysts and hydrogen peroxide. Fuel 2014, 138, 118-125. [CrossRef]

24. Shiraishi, Y.; Tachibana, K.; Hirai, T.; Komasawa, I. Desulfurization and denitrogenation process for light oils based on chemical oxidation followed by liquid-liquid extraction. Ind. Eng. Chem. Res. 2002, 41, 4362-4375. [CrossRef]

25. Ogunlaja, A.S.; Abdul-quadir, M.S.; Kleyi, P.E.; Ferg, E.E.; Watts, P.; Tshentu, Z.R. Towards oxidative denitrogenation of fuel oils: Vanadium oxide-catalysed oxidation of quinoline and adsorptive removal of quinoline-N-oxide using 2,6-pyridine-polybenzimidazole nanofibers. Arab. J. Chem. 2017, in press. [CrossRef]

26. Ishihara, A.; Wang, D.; Dumeignil, F.; Amano, H.; Qian, E.W.; Kabe, T. Oxidative desulfurization and denitrogenation of a light gas oil using an oxidation/adsorption continuous flow process. Appl. Catal. A Gen. 2005, 279, 279-287. [CrossRef]

27. Badoga, S.; Sharma, R.V.; Dalai, A.K.; Adjaye, J. Synthesis and characterization of mesoporous aluminas with different pore sizes: Application in NiMo supported catalyst for hydrotreating of heavy gas oil. Appl. Catal. A Gen. 2015, 489, 86-97. [CrossRef] 
28. Filippo, E.; Carlucci, C.; Capodilupo, A.L.; Perulli, P.; Conciauro, F.; Corrente, G.A.; Gigli, G.; Ciccarella, G.; Street, M.; Street, A.; et al. Enhanced Photocatalytic Activity of Pure Anatase $\mathrm{Tio}_{2}$ and $\mathrm{Pt}-\mathrm{Tio}_{2} \mathrm{Nanoparticles}$ Synthesized by Green Microwave Assisted Route. Experimental Section. Mater. Res. 2015, 18, $473-481$. [CrossRef]

29. Senthilkumar, B.; Vijaya Sankar, K.; Kalai Selvan, R.; Danielle, M.; Manickam, M. Nano $\alpha$-NiMoO 4 as a new electrode for electrochemical supercapacitors. RSC Adv. 2013, 3, 352-357. [CrossRef]

30. Veerasubramani, G.K.; Krishnamoorthy, K.; Sivaprakasam, R.; Kim, S.J. Sonochemical synthesis, characterization, and electrochemical properties of $\mathrm{MnMoO}_{4}$ nanorods for supercapacitor applications. Mater. Chem. Phys. 2014, 147, 836-842. [CrossRef]

31. Heuer, A.H.; Nakagawa, T.; Azar, M.Z.; Hovis, D.B.; Smialek, J.L.; Gleeson, B. SXPS, FTIR, EDX, and XRD Analysis of $\mathrm{Al}_{2} \mathrm{O}_{3}$ Scales Grown on PM2000 Alloy. J. Spectrosc. 2015, 2015, 1-16.

32. Adamczyk, A.; Długoń, E. The FTIR studies of gels and thin films of $\mathrm{Al}_{2} \mathrm{O}_{3}-\mathrm{TiO}_{2}$ and $\mathrm{Al}_{2} \mathrm{O}_{3}-\mathrm{TiO}_{2}-\mathrm{SiO}_{2}$ systems. Spectrochim. Acta-Part A Mol. Biomol. Spectrosc. 2012, 89, 11-17. [CrossRef]

33. Ng, E.-P.; Ghoy, J.-P.; Awala, H.; Vicente, A.; Adnan, R.; Ling, T.C.; Mintova, S. Ionothermal synthesis of FeAPO-5 in the presence of phosphorous acid. CrystEngComm 2016, 18, 257-265. [CrossRef]

34. Klähn, M.; Mathias, G.; Kötting, C.; Nonella, M.; Schlitter, J.; Gerwert, K.; Tavan, P. IR spectra of phosphate ions in aqueous solution: Predictions of a DFT/MM approach compared with observations. J. Phys. Chem. A 2004, 108, 6186-6194. [CrossRef]

35. Ghosh, D.; Giri, S.; Moniruzzaman, M.; Basu, T.; Mandal, M.; Das, C.K. $\alpha \mathrm{MnMoO}_{4} /$ graphene hybrid composite: high energy density supercapacitor electrode material. Dalt. Trans. 2014, 43, 11067-11076. [CrossRef]

36. Yan, X.; Tian, L.; Murowchick, J.; Chen, X. Partially amorphized $\mathrm{MnMoO}_{4}$ for highly efficient energy storage and the hydrogen evolution reaction. J. Mater. Chem. A 2016, 4, 3683-3688. [CrossRef]

37. Kurumada, M.; Kaito, C. Change in IR spectra of molybdenum oxide nanoparticles due to particles size or phase change. J. Phys. Soc. Japan 2006, 75, 2-6. [CrossRef]

38. XPS Data for Elements. Available online: https://xpssimplified.com/periodictable.php (accessed on 10 April 2018).

39. Di Castro, V.; Polzonetti, G. XPS study of MnO oxidation. J. Electron. Spectrosc. Relat. Phenom. 1989, 48, 117-123. [CrossRef]

40. Cerrato, J.M.; Hochella, M.F.J.; Knocke, W.R.; Dietrich, A.M.; Cromer, T.F. Use of XPS to Identify the Oxidation State of Mn in Solid Surfaces of Filtration Media Oxide Samples from Drinking Water Treatment Plants. Environ. Sci. Technol. 2010, 44, 5881-5886. [CrossRef]

41. Majumdar, S.; Elovaara, T.; Huhtinen, H.; Granroth, S.; Paturi, P. Crystal asymmetry and low-angle grain boundary governed persistent photoinduced magnetization in small bandwidth manganites. J. Appl. Phys. 2013, 113, 063906. [CrossRef]

42. Nikolova, D.; Edreva-Kardjieva, R.; Gouliev, G.; Grozeva, T.; Tzvetkov, P. The state of (K)(Ni)Mo/ $\gamma-\mathrm{Al}_{2} \mathrm{O}_{3}$ catalysts after water-gas shift reaction in the presence of sulfur in the feed: XPS and EPR study. Appl. Catal. A Gen. 2006, 297, 135-144. [CrossRef]

43. Castillo, C.; Buono-Core, G.; Manzur, C.; Yutronic, N.; Sierpe, R.; Cabello, G.; Chornik, B. Molybdenum trioxide thin films doped with gold nanoparticles grown by a sequential methodology: Photochemical Metal-Organic Deposition (PMOD) and DC-magnetron sputtering. J. Chil. Chem. Soc. 2016, 61, 2816-2820. [CrossRef]

44. Naumkin, A.V.; Kraut-Vass, A.; Gaarenstroom, S.W.; Powell, C.J. NIST X-ray Photoelectron Spectroscopy Database. Available online: https://srdata.nist.gov/xps/ElmSpectralSrch.aspx?selEnergy=PE (accessed on 10 April 2018).

45. Badoga, S.; Dalai, A.K.; Adjaye, J.; Hu, Y. Insights into individual and combined effects of phosphorus and EDTA on performance of $\mathrm{NiMo} / \mathrm{MesoAl}_{2} \mathrm{O}_{3}$ catalyst for hydrotreating of heavy gas oil. Fuel Process. Technol. 2017, 159, 232-246. [CrossRef]

46. Iwamoto, R.; Grimblot, J. Influence of Phosphorus on the Properties of Alumina-Based Hydrotreating Catalysts. Adv. Catal. 1999, 44, 417-503. [CrossRef]

47. Deng, X.; Quek, S.Y.; Biener, M.M.; Biener, J.; Kang, D.H.; Schalek, R.; Kaxiras, E.; Firend, C.M. Selective Thermal Reduction of Single-layer $\mathrm{MoO}_{3}$ nanostructures on $\mathrm{Au}$ (111). Surf. Sci. 2007, 602, 1166-1174. [CrossRef] 
48. Abdullah, W.N.W.; Ali, R.; Bakar, W.A.W.A. In depth investigation of $\mathrm{Fe} / \mathrm{MoO}_{3}-\mathrm{PO}_{4} / \mathrm{Al}_{2} \mathrm{O}_{3}$ catalyst in oxidative desulfurization of Malaysian diesel with TBHP-DMF system. J. Taiwan Inst. Chem. Eng. 2016, 58, 344-350. [CrossRef]

49. García-Gutiérrez, J.L.; Fuentes, G.A.; Hernández-Terán, M.E.; García, P.; Murrieta-Guevara, F.; Jiménez-Cruz, F. Ultra-deep oxidative desulfurization of diesel fuel by the $\mathrm{Mo} / \mathrm{Al}_{2} \mathrm{O}_{3}-\mathrm{H}_{2} \mathrm{O}_{2}$ system: The effect of system parameters on catalytic activity. Appl. Catal. A Gen. 2008, 334, 366-373. [CrossRef]

50. García-Gutiérrez, J.L.; Fuentes, G.A.; Hernández-Terán, M.E.; Murrieta, F.; Navarrete, J.; Jiménez-Cruz, F. Ultra-deep oxidative desulfurization of diesel fuel with $\mathrm{H} 2 \mathrm{O} 2$ catalyzed under mild conditions by polymolybdates supported on $\mathrm{Al}_{2} \mathrm{O}_{3}$. Appl. Catal. A Gen. 2006, 305, 15-20. [CrossRef]

51. Shen, C.; Wang, Y.J.; Xu, J.H.; Luo, G.S. Oxidative desulfurization of DBT with $\mathrm{H}_{2} \mathrm{O}_{2}$ catalysed by $\mathrm{TiO}_{2}$ /porous glass. Green Chem. 2016, 18, 771-781. [CrossRef]

52. Badoga, S. Synthesis and Characterization of NiMo Supported Mesoporous Materials with EDTA and Phosphorus for Hydrotreating of Heavy Gas Oil. Ph.D. Thesis, University of Saskatchewan, Saskatoon, SK, Canada, 2015.

(C) 2018 by the authors. Licensee MDPI, Basel, Switzerland. This article is an open access article distributed under the terms and conditions of the Creative Commons Attribution (CC BY) license (http://creativecommons.org/licenses/by/4.0/). 